\title{
Archaeological Survey for the Planned First Responders Academy, Bexar County, Texas
}

Antonia L. Figueroa

Center for Archeological Research, University of Texas at San Antonio

Follow this and additional works at: https://scholarworks.sfasu.edu/ita

Part of the American Material Culture Commons, Archaeological Anthropology Commons, Environmental Studies Commons, Other American Studies Commons, Other Arts and Humanities Commons, Other History of Art, Architecture, and Archaeology Commons, and the United States History Commons

Tell us how this article helped you.

This Article is brought to you for free and open access by the Center for Regional Heritage Research at SFA ScholarWorks. It has been accepted for inclusion in Index of Texas Archaeology: Open Access Gray Literature from the Lone Star State by an authorized editor of SFA ScholarWorks. For more information, please contact cdsscholarworks@sfasu.edu. 


\section{Archaeological Survey for the Planned First Responders Academy, Bexar County, Texas}

\section{Creative Commons License}

(c) (1) (8)

This work is licensed under a Creative Commons Attribution-NonCommercial 4.0 International License 


\section{Archaeological Survey for the Planned First Responders Academy, Bexar County, Texas}

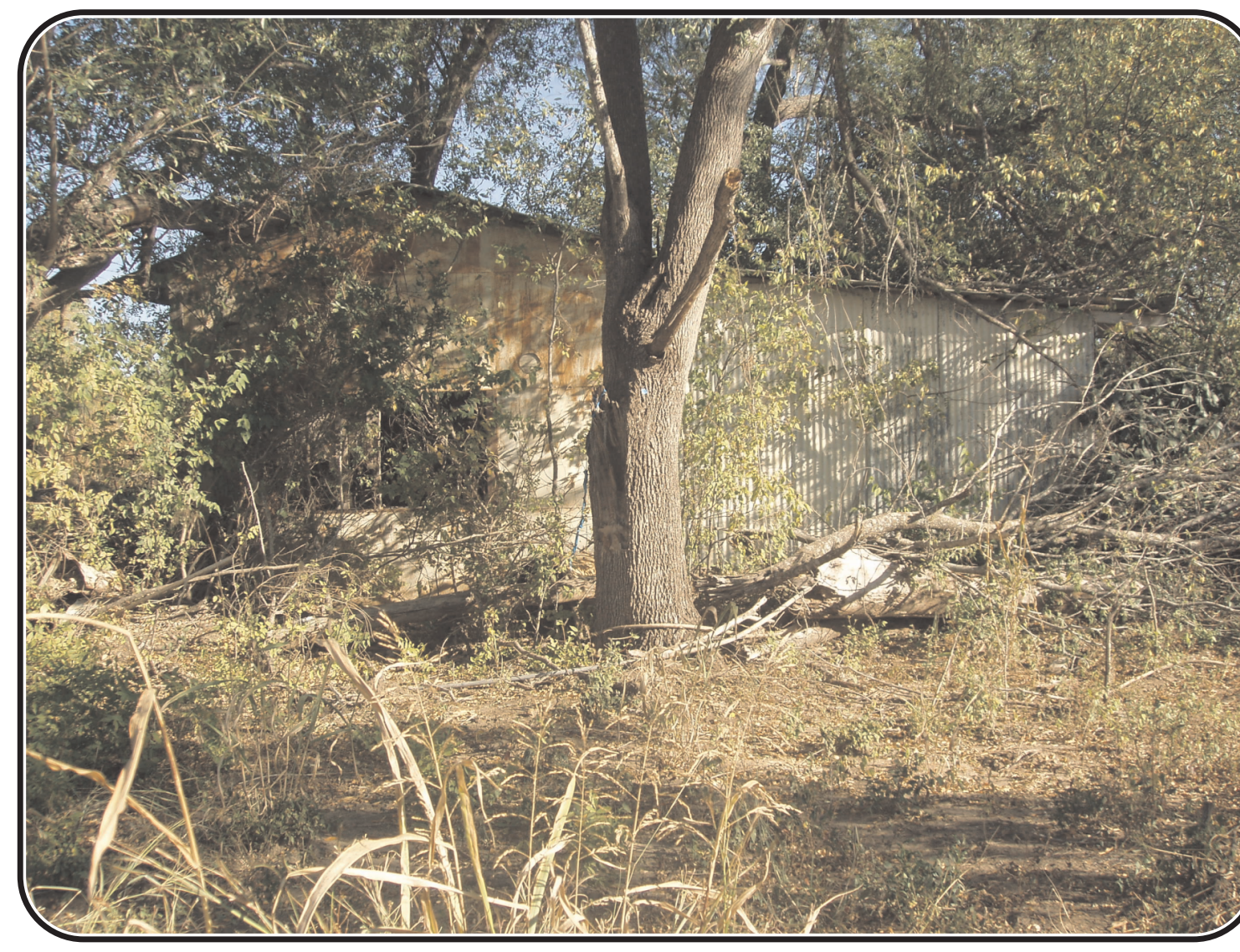

by

Antonia L. Figueroa

Texas Antiquities Permit No. 5084

Prepared for:

O'Neill Conrad Oppelt Architects, Inc.

114 E. Cevallow Drive

San Antonio, Texas 78204

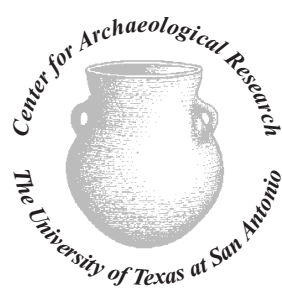

(C)2009
Prepared by:

Center for Archaeological Research The University of Texas at San Antonio Archaeological Report, No. 401 


\title{
Archaeological Survey for the Planned First Responders Academy, Bexar County, Texas
}

\author{
by \\ Antonia L. Figueroa
}

Texas Antiquities Committee Permit No. 5084

Principal Investigator

Kristi M. Ulrich

Prepared for:

O’Neill Conrad Oppelt Architects, Inc.

114 E. Cevallow Drive

San Antonio, Texas 78204
Prepared by:

Center for Archaeological Research The University of Texas at San Antonio Archaeological Report No. 401 



\begin{abstract}
:
The Center for Archaeological Research at The University of Texas at San Antonio performed an archaeological survey for the planned First Responder Academy, Bexar County, Texas. The work was conducted for O’Neil Conrad Oppelt Architects, Inc. As a result of the archaeological survey two new sites were recorded. 41BX1789, a historic site, consisted of a historic structure along with household debris. 41BX1790, identified as a prehistoric site, consisted of a light scatter of lithic debitage and burned rock. One of the Medina Lake irrigation canals runs along the perimeter of the project area and many areas are inundated due to seepage from the canal. Portions of the project area have been disturbed by preliminary construction of the First Responders Academy and planting associated with the Aldridge Nursery (former land owners). The project was performed under Texas Antiquities Permit \# 5084 with Kristi M. Ulrich serving as Principal Investigator and Antonia L. Figueroa serving as Project Archaeologist.
\end{abstract}

All materials recovered during the investigations and project related documents are curated at the Center for Archaeological Research. 


\section{Table of Contents:}

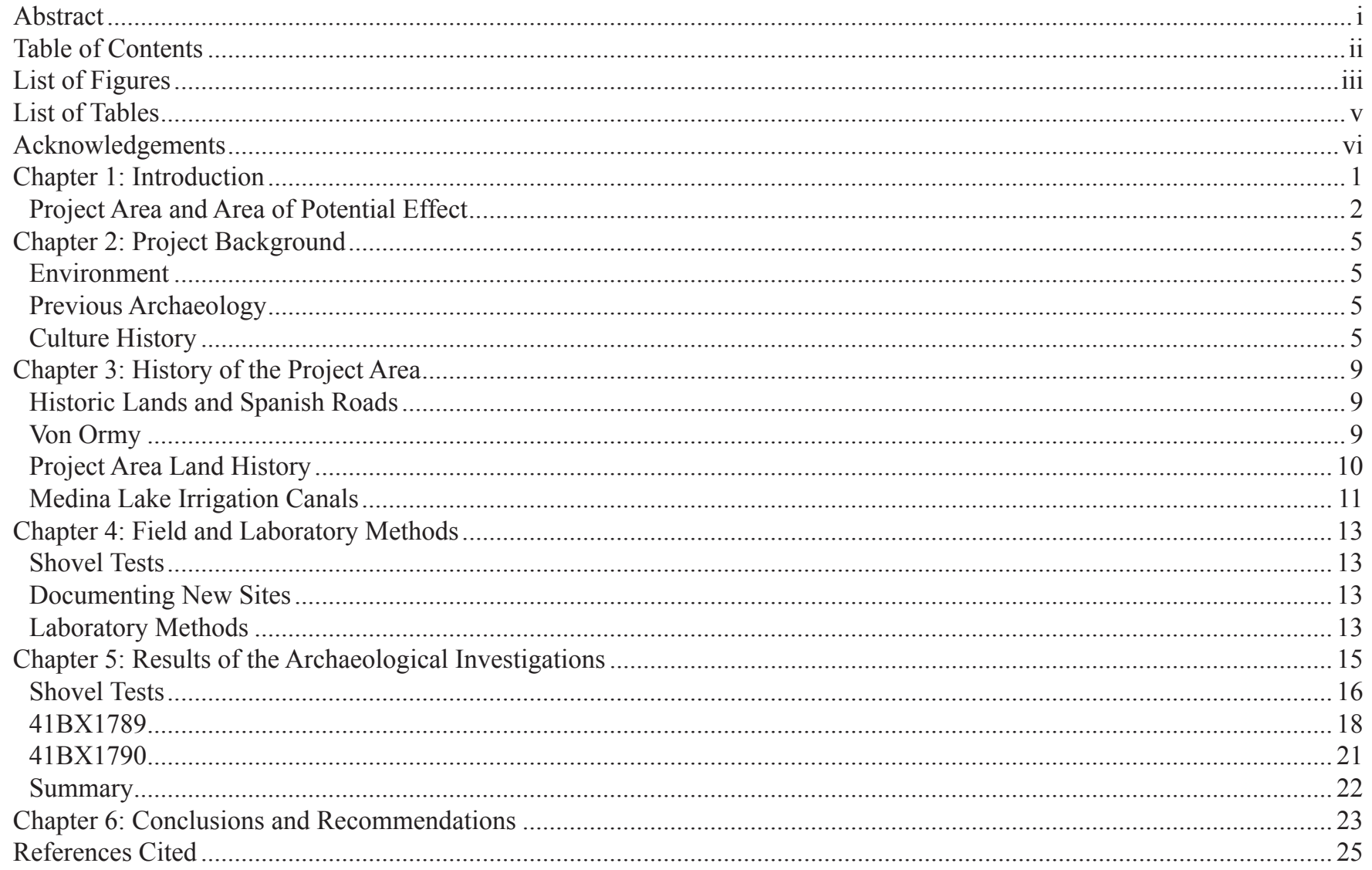




\section{List of Figures:}

Figure 1-1. Location of the project area in southeastern Bexar County, Texas .................................................................. 1

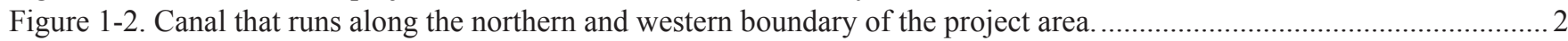

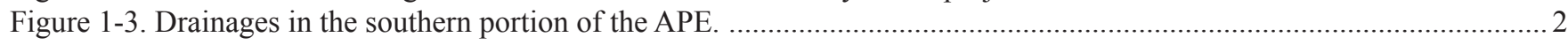

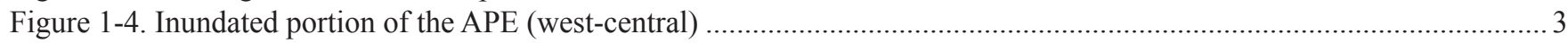

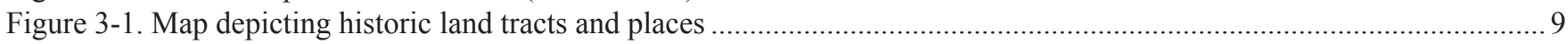

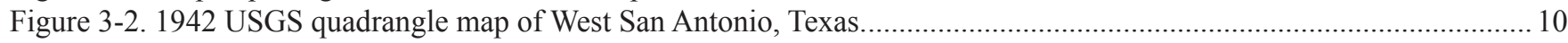

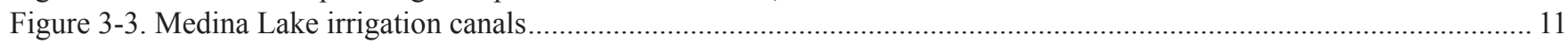

Figure 5-1. Aerial photograph of the project area depicting shovel tests. .................................................................... 15

Figure 5-2. Impacts from preliminary construction of the First Responders Academy.......................................................... 16

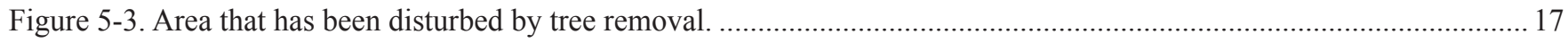

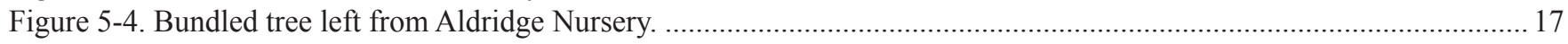

Figure 5-5. Sketch map of 41BX1789.

Figure 5-6. Two room structure at 41BX1789 (facing east).................................................................................. 19

Figure 5-7. East room of structure at 41BX1789, note exposed metal walls and wooden frame (facing southeast)...... 20

Figure 5-8. North façade of structure at 41BX1789 with attached bathroom and open shed...............................................20

Figure 5-9. Debris pile south of structure containing wooden beams, glass, metal and ceramics. .....................................22

\section{List of Tables:}

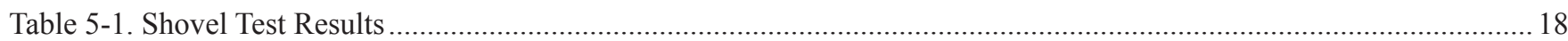

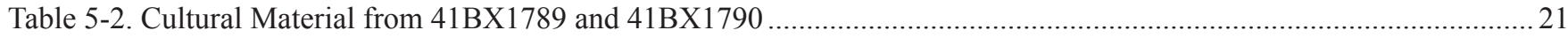




\section{Acknowledgements:}

The pedestrian survey could not have been completed without the field crew that included Nathan Divito, Jason Perez and Steve Smith. Laboratory duties were conducted by Jason Perez and Steve Smith under the direction of Marybeth Tomka (laboratory director). Mickey Conrad with O'Neill Conrad Oppelt Architects, Inc. and Kay Hindes with the City of San Antonio Historic Preservation Office were essential in the completion of the project. Thanks to Principal Investigator Kristi M. Ulrich. Thanks to Steve Tomka (director) for his support during the project. Jennifer L. Thompson provided comments on the draft report. Drafting of report figures and the editing of the final report was completed by Bruce Moses. 


\section{Chapter 1: Introduction}

In November 2008 the Center for Archaeological Research of The University of Texas at San Antonio (CAR-UTSA) conducted archaeological investigations for the planned First Responders Academy located in southeast Bexar County, Texas (Figure 1-1). The CAR was contracted by O'Neil Conrad Oppelt Architects, Inc. to perform a pedestrian survey of the approximately 60 - acre area that will be impacted by the planned First Responders Academy. As a result of the survey, 34 shovel tests were excavated and two sites were documented. 41BX1789 is a historic site that includes a historic structure and debris, while 41BX1790 was identified as a prehistoric site. CAR does not recommend further work on either site. The archaeological investigations were conducted under Texas Antiquities Permit \#5084 with Kristi

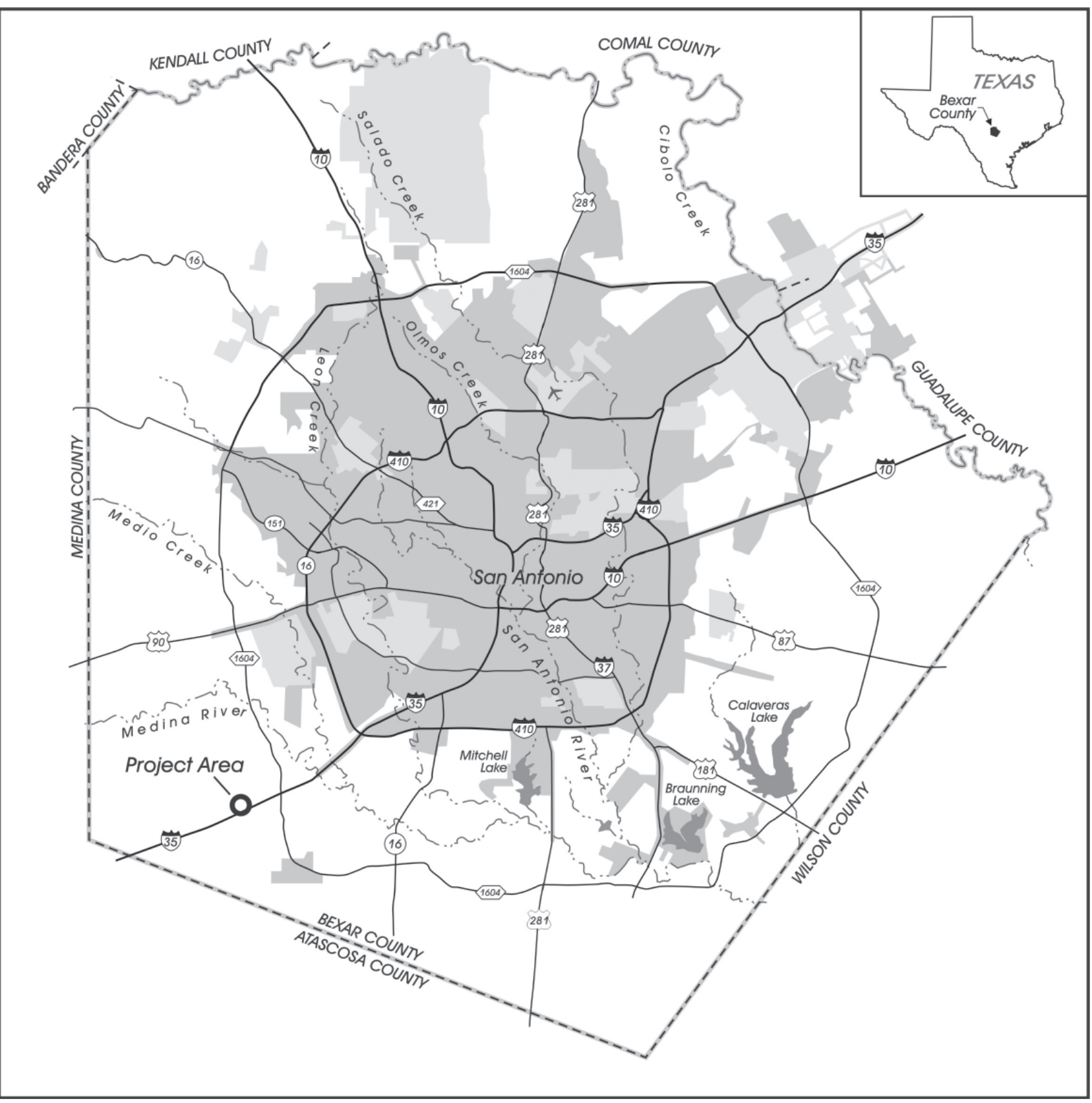

Figure 1-1. Location of the project area in southeastern Bexar County, Texas 
M. Ulrich serving as Principal Investigator and Antonia L. Figueroa serving as Project Archaeologist.

The project is being carried out by a political subdivision of the State of Texas; therefore, it falls under the jurisdiction of the Antiquities Code of Texas administered by the Texas Historical Commission. The project will also require several City permits and therefore falls under the oversight of Chapter 35 of the Unified Development Code of the San Antonio Historic Preservation Division.

\section{Project Area and Area of Potential Effect}

The project area is located off Interstate 35, just southwest of Loop 1604 and is depicted on the MacDona 7.5 Minute Series USGS quadrangle map. The project area, also the Area of Potential Effect (APE), consists of 60 acres which will be impacted by construction associated with the proposed First Responders Academy. The APE is bound by Herring Road to the west and IH 35 to the south. The northern part of the project area is an open agricultural field. A canal that is part of the Medina drainage canal system runs along the northern and western boundaries of the project area (Figure 1-2). Portions of the project area, in the west-central half, are inundated with water as a result of seepage from the canal system and associated drainages that run through the APE. (Figures 1-3 and 1-4).

Prior to the archaeological survey, approximately nine acres had been impacted by the preliminary construction of the First Responders Academy. The project area has also been impacted by activities associated with the Aldridge Nursery that once occupied the land.

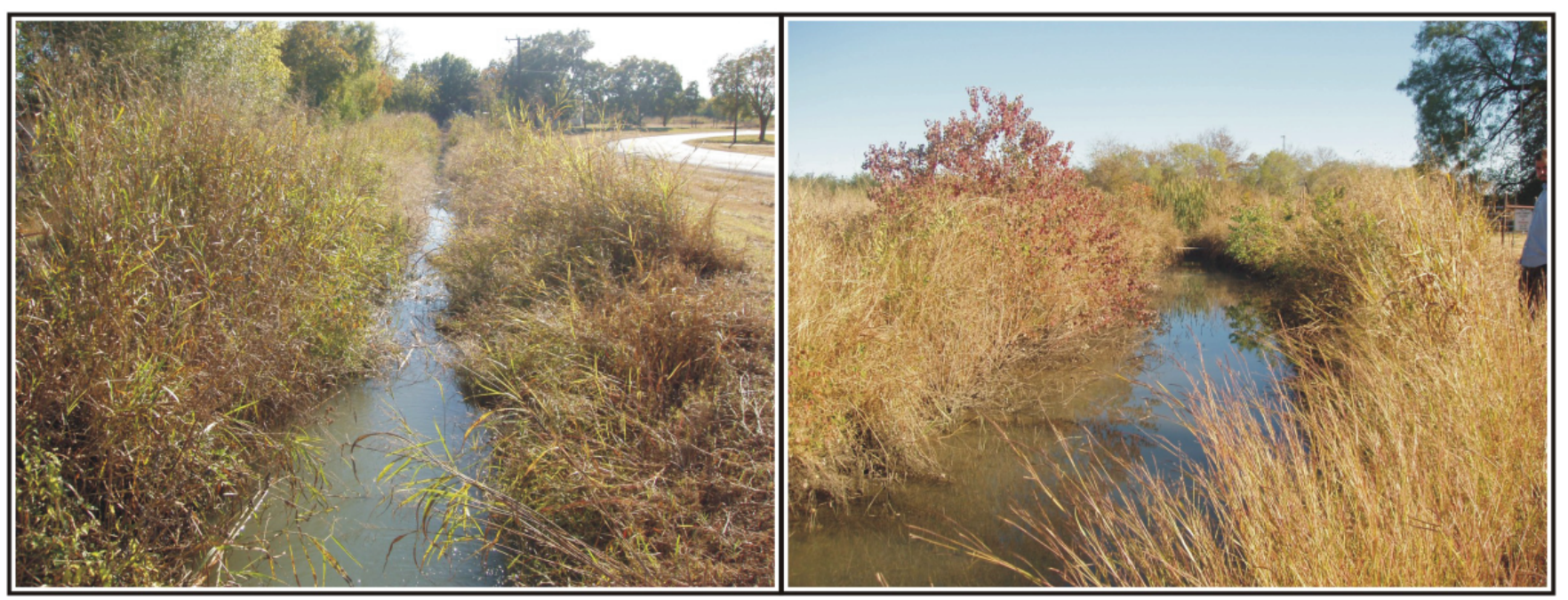

Figure 1-2. Canal that runs along the northern and western boundary of the project area.

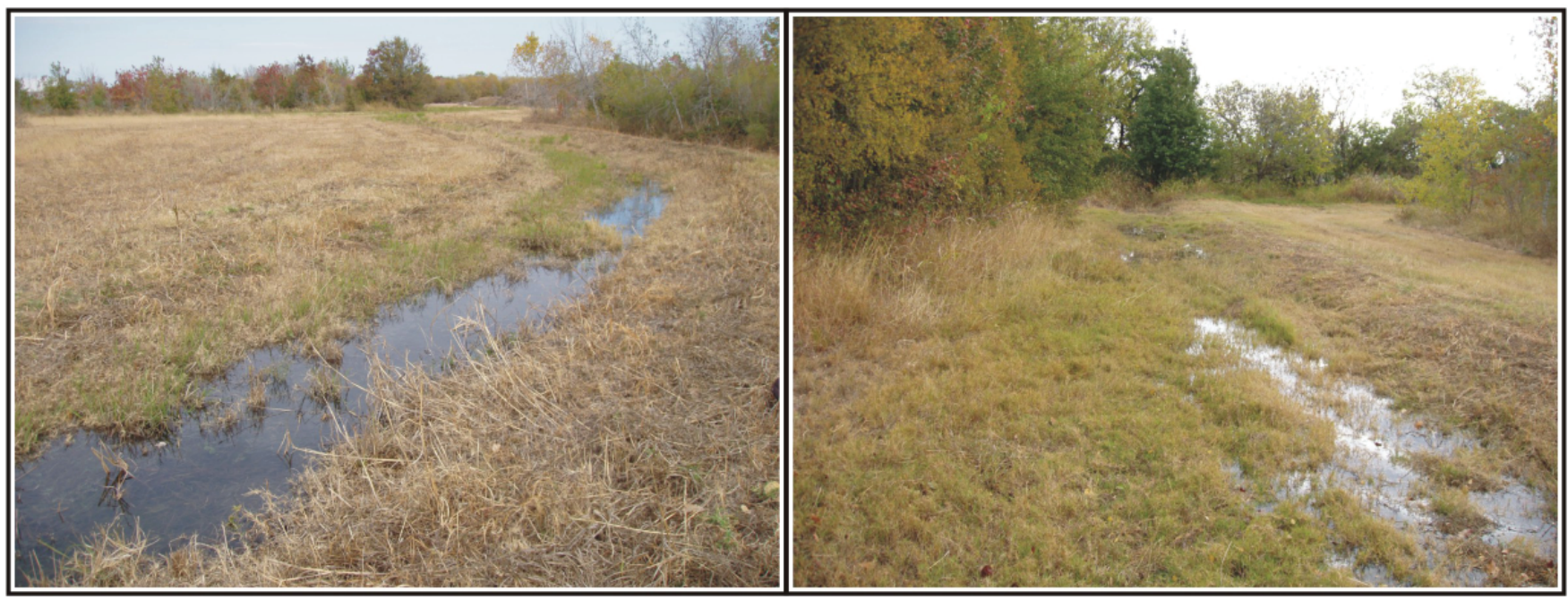

Figure 1-3. Drainages in the southern portion of the APE. 


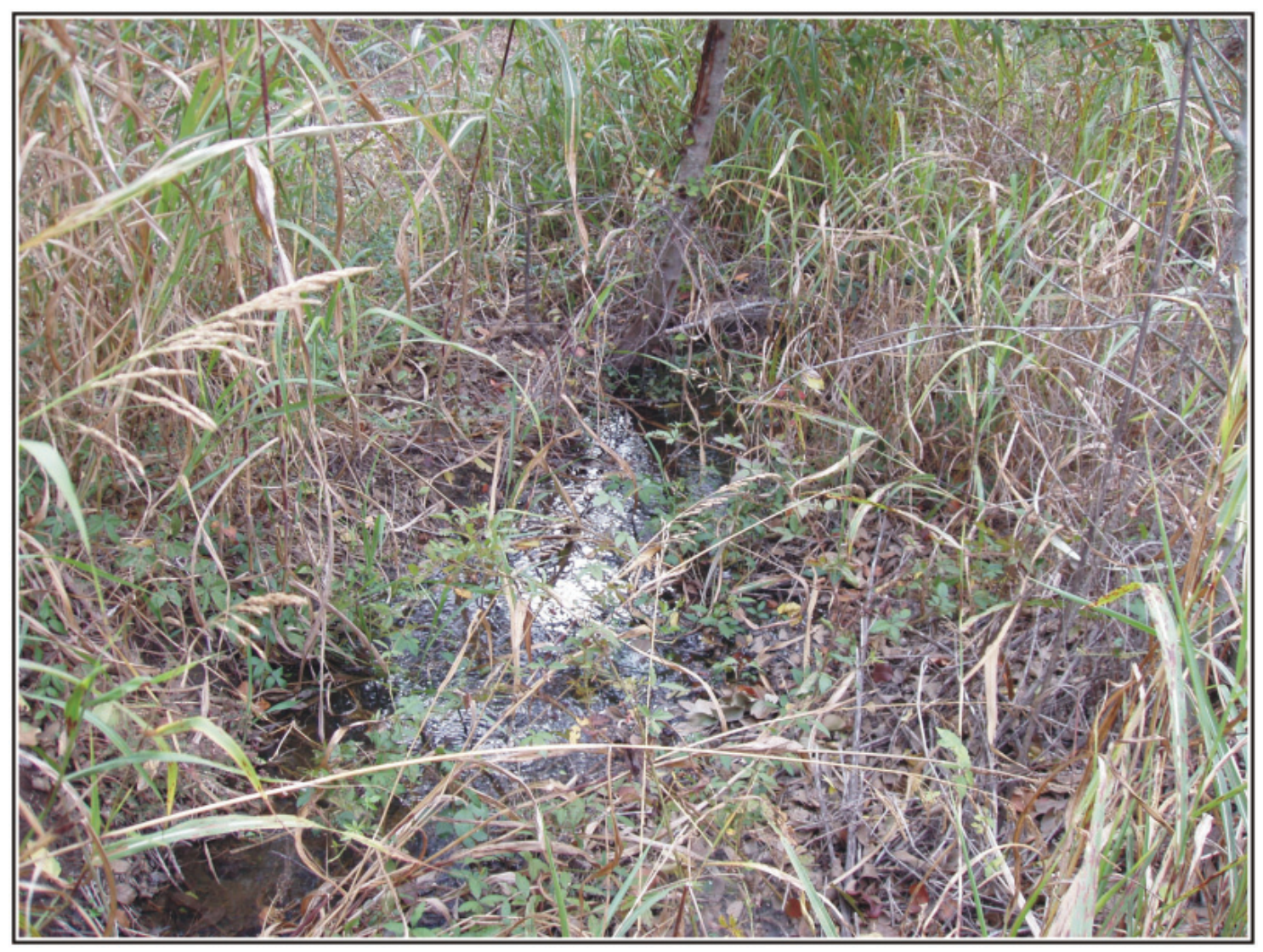

Figure 1-4. Inundated portion of the APE (west-central) 



\section{Chapter 2: Project Background}

In this chapter, the background of the project area is given including the environment, previous archaeology and a culture history of South Texas and the APE. This section begins with a brief discussion on the environment. Only two sites have been documented within three miles of the project area and are discussed in the previous archaeology section. The chapter is concluded with a culture history of southcentral Texas.

\section{Environment}

The APE is situated south of the Edward's Plateau and below the Balcones Escarpment. Elevations in the project area range from 600 to 650 feet amsl. The nearest natural water sources are Lost Pond to the east and Oak Creek to the west. Medina River is approximately 3 miles to the northeast. The vegetated portions of the APE are dominated by Red Oak (Quercus texana) planted when the nursery occupied the land.

The APE is located between the South Texas Brush Country and the Blackland Prairie. Much of the area within the APE has been impacted by agricultural activities and a nursery that once occupied some of the land. The climate in this region is typically subtropical with cool winters and hot summers (Taylor et al. 1991). Annual temperatures range from an average low of $37.9^{\circ} \mathrm{F}$ in January to an average high of 95. $0^{\circ}$ in July (Bomar 1999). Annual average rainfall for San Antonio is 30.98 inches (Bomar 1999).

The Crockett Series soils dominate much of the southern third of the county. The surface layer averages 10-inches in thickness. At the surface, Crockett soils are dark brown, nonclacareous, and easily worked. These soils are naturally well drained and moderately suited to dryland crops like corns and sorghum. They are also commonly used for pasture as they support native grasses well (Taylor et al. 1991).

Crockett Fine Sandy Loam, 1 to 3 percent slope, is present within the boundaries of the project area. This soil type is the most common in southern Bexar County and susceptible to water erosion. (Taylor et al. 1991).

\section{Previous Archaeology}

Only two archaeological sites have been documented within three miles of the project area. The Meyer Pottery
Archeological Complex (41BX128) is 2.5 miles west of the project area. The site is listed on the National Register of Historic Places (NRHP). The pottery site is west of the former Schultz and Meyers residence and consists of large quantities of stoneware sherds associated with a collapsed down draft type kiln (THC 2008a).

41BX439 is located over 2 miles from the project area and was recorded in 1977 by Al Leippe. The site is located north of IH-35 in Von Ormy. A surface collection of artifacts included point fragments, scrapers, Guadalupe gouges and choppers (THC 2008a).

\section{Culture History}

This section summarizes the culture history for the region. Due to the presence of both prehistoric and historical sites in the vicinity of the APE, this discussion begins with the Paleoindian period and concludes with the historical period of Texas.

\section{Paleoindian (11500-8800 BP)}

The Paleoindian Period corresponds with the earliest documented presence of humans in Bexar County between 11500-8800 B.P (Collins 1995). Subsistence patterns during this time focused on large, highly mobile mega fauna but also included the exploitation of small to medium fauna. This period is typically divided into early and late segments. The early portion of the period is associated with Clovis and Folsom adaptations. Lithic technology includes fluted Clovis and Folsom projectile points. In the later portion of the period there were stylistic changes in projectile point technology seen in Dalton, Scottsbluff, and Golondrina traditions. While widespread in geographic range, these types occurred in high densities in the High Plains and Central Texas (Meltzer and Bever 1995). As the climate warmed, megafauna gradually died off, and subsistence patterns shifted.

\section{Archaic (8800-1200 BP)}

This period is subdivided into the Early, Middle and Late subperiods. The subperiods are distinguished by differences in climate conditions, resource availability, subsistence practices and temporally diagnostic projectile points (Collins 1995). Plant gathering appears to have become an important part of subsistence strategies during this period, 
and was probably even more important during xeric periods. Environmental conditions may explain the appearance of burned rock earth ovens during the period. They were used to cook a variety of plant foods that were otherwise inedible, such as the roots of sotol, and yucca (Collins 1995: 383).

In the Early Archaic (8800-6000 BP), the subsistence shifted from hunting large game to hunting medium and small species and gathering plant foods (Collins 1995). Projectile point styles include Angostura and Early Split Stemmed. Task-specific tools include Clear Fork gouges and Guadalupe and Nueces bifaces (Turner and Hester 1993:246, 256). Early Archaic sites are located along the eastern and southern portions of the Edwards Plateau in areas with reliable water sources (McKinney 1981). Population densities were relatively low during this subperiod and consisted of small highly mobile bands (Story 1985:39).

The Middle Archaic spans from 6000 to 4000 BP (Collins 1995). Diagnostic projectile points from this period include Bell, Andice, Taylor, Nolan, and Travis. According to Collins (1995), during the Middle Archaic there was a focus on large-game hunting of bison. However, recent studies suggest an absence of bison during the Middle Archaic (Mauldin and Kemp 2005). Climate was gradually drying as the onset of the Altithermal drought began. Demographic and cultural change likely occurred in response to these hotter and drier conditions.

The last subperiod of the Archaic is the Late Archaic that spans 4000 to 1200 BP (Collins 1995). Dart point diagnostics of the Late Archaic are triangular points with corner notches that include Ensor and Ellis (Turner and Hester 1993:114,122). Other Late Archaic projectile points are Bulverde, Pedernales, Marshall, and Marcos types (Collins 1995). Evidence from the Thunder Valley sinkhole cemetery suggests that territoriality may have established during the Late Archaic, possibly as a result of population increase (Bement 1989). Some researchers state the accumulation of burned rock middens ceased at this time though current research has challenged this notion (Black and Creel 1997; Mauldin et al. 2003).

\section{Late Prehistoric (1200-350 BP)}

The Late Prehistoric period is marked by the Austin and Toyah phases. During the Austin Phase the bow and arrow was introduced. Nickels and Mauldin (2001) suggested at the beginning of this period environmental conditions were warm and dry. More mesic conditions appear to accelerate after 1000 BP. Subsistence practices remain relatively unchanged, especially during the Austin Phase. The Austin
Phase may represent the most intensive use of burned rock middens (Black and Creel 1997), and includes temporally diagnostic point types Scallorn and Edwards (Collins 1995; Turner and Hester 1993).

The presence of bone tempered ceramics (Leon Plain) during the Toyah Phase suggests interaction between Central Texas and ceramic producing traditions in East and North Texas (Perttula et al. 1995). Ceramics were in common use in East Texas by 2450 BP, but the first Central Texas wares did not appear until ca. 650-700 BP. Other technological traits of this phase include the temporally diagnostic Perdiz point and beveled bifaces. These specialized processing kits are thought to be an adaption to flourishing bison populations by some (Ricklis 1992) and a sign of intensification of exploitation of declining bison populations by others (Mauldin et al. 2006).

\section{Protohistoric (ca. 1528-1700)}

The Protohistoric period is a term typically used to describe the transition between the Late Prehistoric and the Colonial period. This period is not well documented archaeologically in Texas. Some researchers (Wade 2003) argue that the Protohistoric period may coincide with the end of the Late Prehistoric Toyah Interval, spanning the period of A.D. $1250 / 1300$ to A.D. $1600 / 1650$ (Hester 1995). For the purposes of this report we define the period as beginning with the Early Spanish explorations in Texas (ca. 1528) and ending with the establishment of a strong Spanish presence in the region in the late 1600 s and early 1700 s.

During this period, there was intermittent contact between the native groups and Spanish explorers. It was a time before the Spanish economy significantly impacted the indigenous groups in the area. A number of encounters between the indigenous communities and Europeans were recorded during this period, including those of Cabeza de Vaca (15281536) and the French settlement established by Rene Robert Cavelier, Sieur de La Salle (1685-1689). The Spanish sent General Alfonso de Leon into the area in 1689, and in 1691 the area of present-day San Antonio was first visited by Domingo de Teran.

Archaeologically, the time period is poorly documented but has been identified at several sites in south Texas counties (e.g., Hall et al. 1986; Inman et al. 1998; Mauldin et al. 2004). A problematic issue concerning this time period is that there is not a clear material culture associated with the period. Therefore, it is difficult to document this time period archaeologically without absolute dates. Sites that have been deemed as "Protohistoric" may have Late Prehistoric and/or Historic artifacts associated with them, and in several cases 
radiocarbon dates confirm their Protohistoric designation (Mauldin et al. 2004).

\section{The Colonial and Mission Periods in San Antonio (ca. 1700-1800)}

The first Spanish presidios in North America began to appear in 1565 with the establishment of San Agustin on the Atlantic coast of Florida (Moorhead 1991:27). The establishment of the presidios was mainly due to the encroachment of European powers, predominantly the French (Moorhead 1991:27). The first attempt to have an established Spanish presence in Texas was the founding of Mission San Francisco de los Tejas, established in 1690 near Nacogdoches, and Santismo Nombre de Maria, built on the banks of the Neches River in that same year. Both attempts were short-lived, and by 1693, both were adandoned (Fox and Cox 2000). The founding of Mission San Juan in 1700 along the Rio Grande marked the beginning of an established Spanish presence in the region (Weddle 1968).

In 1718, Don Martín del Alarcón established Presidio San Antonio de Béxar and Mission San Antonio de Valero near the headwaters of San Pedro Creek (Chipman 1992:14; Hoffman 1937). In 1722, Marqués de Aguayo relocated the villa and presidio to their final locations on the west side of the San Antonio River. The presidio and the villa were named after the Duke of Béjar, the elder brother of the Viceroy (Buerkle 1976:50). The purpose of the San Antonio de Bexar presidio was not only to protect the mission, town, farms and ranches, but also serve as a way-station between Mexico and the East Texas settlements. After a four-month stay in East Texas, Alarcón returned to San Antonio where he faced challenges and problems with the missionary fathers (Buerkle 1976:51). After his request for additional soldiers, funds, and supplies was denied, Alarcón resigned from his position in 1719 (Buerkle 1976:51).

In 1719, Marqués de San Miguel de Aguayo became the governor and captain general of Coahuila and Texas. He led an expedition into Texas to return Spanish presence to the frontier. Aguayo and his troops re-supplied in San Antonio before returning to East Texas for eight months. While in East Texas, Aguayo re-established the presidios and installed new missions (Buerkle 1976:52). Upon his return to San Antonio, he found that the granary at the presidio, along with several of the soldiers' jacales, had been destroyed by fire. Aguayo ordered that a new presidio be built of adobe. Harsh weather delayed the progress of the new presidio and it was apparently never completed. The construction never "progressed beyond two towers, a surrounding wall and some scattered wooden or jacal structures" (Buckley 1991).
In 1720, Mission San José y San Miguel de Aguayo was established in the area, followed by the missions Nuestra Señora de la Purisima Concepción de los Hainai, San Francisco de Espada and San Juan Capistrano. The establishment of Villa de San Fernando occurred in 1731. The settlement was to be home to Canary Islanders (Isleños). The villa became the first civilian settlement of Texas.

The Seven Year War began in 1756 and changed the dynamics of Spanish colonialism in Texas. The British replaced the French as a major threat to Spanish presence, and Spain had to fortify its settlements in Louisiana and California against indigenous groups. As a result of this shift in focus, East Texas settlements began to deteriorate and populations were relocated to San Antonio. During the later part of the eighteenth century, the missions in San Antonio began to decline due to a shortage of priests and a decline in population and workers to maintain the agricultural fields.

In 1790, Manuel Silva, under the College of Zacatecas, recommended that Mission San Antonio de Valero be secularized. Furthermore, of the four remaining missions only two were still functioning. By 1794, Mission San Antonio de Valero was secularized and the surrounding lands distributed to the remaining Mission Indians and other individuals.

\section{Early Texas (1800-1836)}

In 1802 the Compania Volante de San Carlos del Alamo de Parras from Coahuila occupied the Presidio de San Antonio de Béxar (Cox 2005). The soldiers were assigned quarters in the abandoned Mission San Antonio. It was at this time that the former mission became known as the Alamo.

Discontent with New Spain in the northern provinces led to the Hidalgo revolt in 1810. Mexico became independent from Spain in 1821. The 1824 constitution merged Texas and Coahuila into one state, with San Antonio de Béxar as a separate department (Fox et al. 1997).

Spain's attempt to regain control of Mexico in 1829 failed. Stephen F. Austin asked San Antonio to provide support for his efforts to make Texas a separate entity in 1833 . The same year, Santa Ana became the President of Mexico.

General Cós and his troops were pushed out of San Antonio under Ben Milam in December of 1835. The Mexican army arrived in San Antonio in February 1836 and the Alamo and Texan troops were assaulted and defeated in early March of 1836. Later that year, Santa Ana was finally defeated and caught at the Battle of San Jacinto (Fox et al. 1997). 


\section{The Republic of Texas (1836-1845)}

Sam Houston was inaugurated as the first president of the Republic of Texas in 1836. The Texas Congress set the boundaries for the newly formed republic as the Rio Grande in the south and Louisiana eastern boundary (Nance 2004). The population of San Antonio increased due to immigration. The new city council of San Antonio elected John W. Smith as mayor in 1837.

Mexico refused to recognize the independence of Texas and a formal state of war continued. General Rafael Vasquez, with 700 soldiers, attempted to take over San Antonio and the unprepared Texan force retreated to present-day Seguin. In 1842, a friend of Santa Ana, General Adrian Woll, captured San Antonio, and this time the Texans resisted. Finally, in 1844 a truce was called between Mexico and Texas (Fox et al. 1997).

\section{The State of Texas (1845-1900)}

On December 29, 1845, the United States Congress approved the Texas State Constitution and Texas was admitted as a state. This act, coupled with the failure to agree on the Rio Grande as a boundary and on the sale of California to the United States, resulted in the war between the United States and Mexico (1846-1848). In early 1846, General Zachary Taylor advanced to the Rio Grande, occupying land that the Mexican government viewed as its own, and war was declared in May of that year. After a series of battles, the United States military occupied Mexico City in August of 1847. In May of 1848, the ratification of the Treaty of Guadalupe Hidalgo by the Mexican government signaled the end of hostilities, established the Rio Grande as a boundary, and gave the United States present-day Arizona, California, New Mexico, Texas and parts of Colorado, Nevada and Utah in exchange for \$15 million. United States troops left Mexico in June of that same year (Bauer 1974; Wallace 1965).

With the boundaries of Texas now established, the new state soon found itself embroiled in controversy over its position on slavery. The majority of the population within the state was derived from the south, and while ranching and subsistence farming were probably the major economic activities, cottonbased agriculture was the major cash crop. In 1846, Texas had more than 30,000 black slaves, many associated with cotton production. At the breakout of the Civil War, thousands of Texans fought on both sides, with the effects of the war seen throughout Texas, including shortages of commodities in San Antonio. On June 19, 1865, General Gordon Granger arrived in Galveston with Union forces, signaling the end of the Civil War (Fox et al. 1997).

In February 1877, the Galveston, Harrisburg and San Antonio Railroad arrived in the area. With the arrival of the railroad, commercial elements were introduced into the area for the first time (Fox et al. 1997). A growth in business was created near the depot, including stores and saloons. City waterworks also commenced during this time and the city continued to expand. At the beginning of the twentieth century, the population of San Antonio was just over 53,000 (Fox et al. 1997). 


\section{Chapter 3: History of the Project Area}

This chapter presents the history of the project area which begins with a discussion of the historic lands and roads specifically in southwest Bexar County that date to the early part of the 19th century. The nearest community to the project area is Von Ormy and a brief history of the town is presented. The chapter concludes with a history of the project area's land transactions.

\section{Historic Lands and Spanish Roads}

Several roads associated with the Spanish Colonial Camino Real crossed through south Bexar County including the Laredo Road, the Upper Presidio Road and the Camino de la Pita. One road that crossed to the northwest of the project area was the Camino de la Pita (Figure 3-1). Esatablished in 1805 (BCA 1809), the Camino de la Pita served as the southern boundary of Rancho San Lucas, the Mission San Jośe y San Miguel del Aguayo ranchlands (McGraw et al. 1998:146). The intersection of the Camino Pita and modern day Elm Creek marks the historic southeastern boundary of the Spanish ranch (McGraw et al. 1998:146).

There are several lands and markers (see Figure 2-1) of historical significance that are mentioned in the survey notes of the Pérez land (Pérez et al. vs. Paschal et al. 1847). Alto de Encinos was a land grant located at a dry pond called Laguna de Tio Albeirto and was marked by a large thicket of live oaks. Paraje San Simon consisted of one to two miles of land occupied by herds of mustangs (Pérez et al. vs. Paschal et al. 1847). This land was part of the Synjuana Hills, where a battle between the Lipan Apache and the Spaniards is said to have occurred (Pérez et al. vs. Paschal et al. 1847). The Llano Rosales (also known as Hog Wallow Prairie) is a prairie that was mentioned during the survey of the Pérez land and spanned two miles wide and three to four miles long.
The APE is situated on lands that were once part of the Alex Bustillos original grant Survey No. 56 (see Figure 3-1). The land owned by Bustillos abutted a large amount of land once owned by Juan Ygnacio Pérez including the Perez Ranch, 41BX274 (Ulrich et al 2008, Weston 2004). Pérez was granted the land in 1808 (McGraw and Hindes 1987:111), though his occupation of the land begin around 1793. The tract of land owned by Pérez was originally part of lands that belonged to Mission San José Y San Miguel de Aguayo (Jackson 1986:39).

\section{Von Ormy}

The APE is approximately three miles southwest of the community of Von Ormy. The community was first settled after the Civil War. The post office was established in 1879 and named Manns' Crossing (see Figure 3-1) after the family

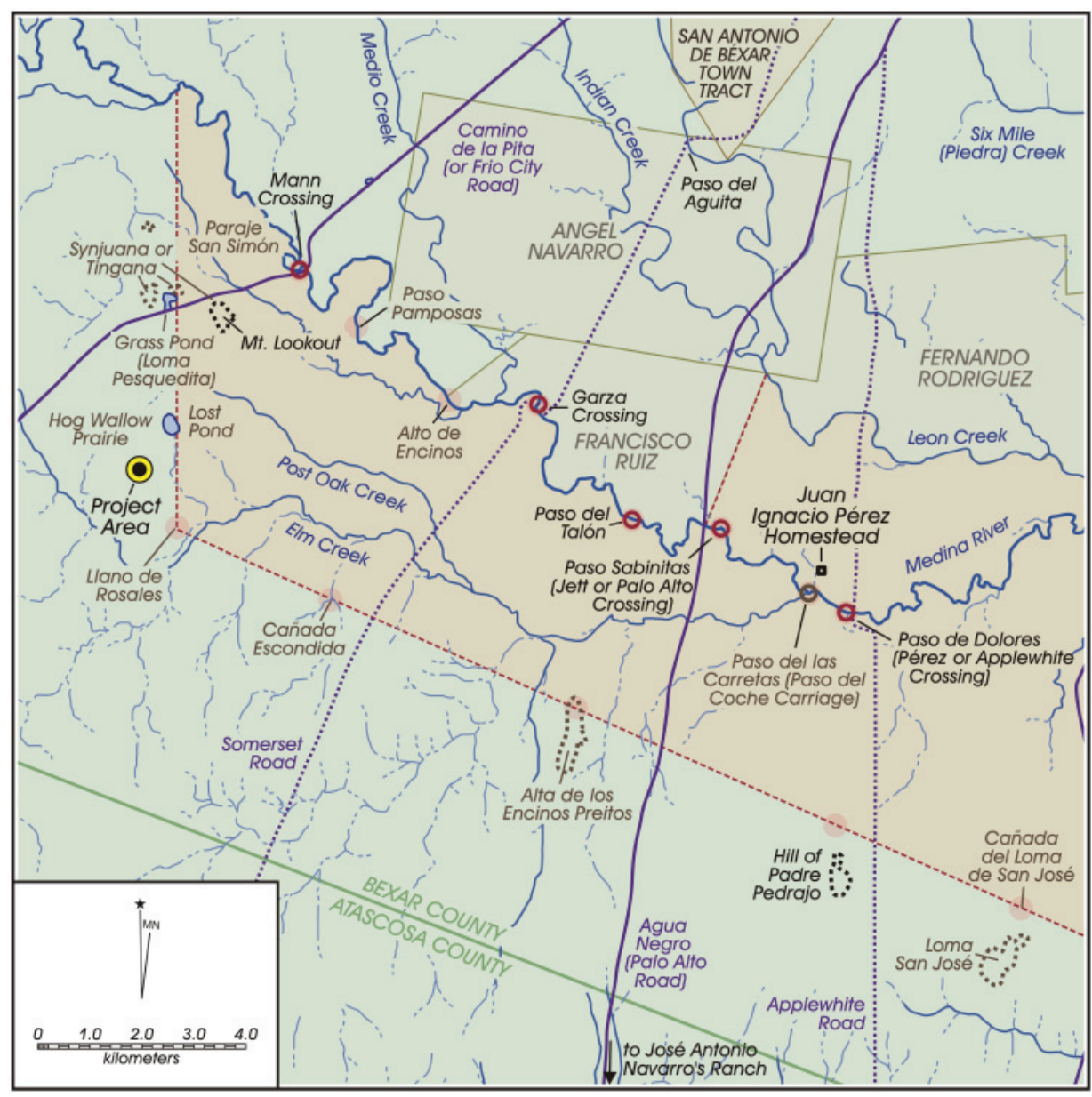

Figure 3-1. Map depicting historic land tracts and places. 
who operated the ferry (Long 2008). One of the founding members of Von Ormy was Enoch Jones (VOHS 2008). Jones purchased a large quantity of land and had his home, a barn and other outbuildings built on the property. Jones died on August 7, 1863 (VOHS 2008). The Von Ormys purchased the land in 1856. The name of the community was changed to Von Ormy in 1886, in honor of the Austrian nobleman, Count Adolph von Ormy. The Count and his wife occupied the mansion with several servants intending to hold royal court there but returned to Europe a year later (VOHS 2008).

The population of Von Ormy in 1914 was 350 which declined after World War II. In 1990 the community had a reported 264 residents and 20 businesses (Long 2008).

\section{Project Area Land History}

The deed and property research of the project area lands was conducted to describe a history of land ownership and also to date the structure recorded during CAR's survey on site 41BX1789.
The original grantee of the land was Alexos Bustillos, as indicated on a map of Bexar County (Original Survey Map No. 56) completed by the General Land Office, Austin, Texas (Boggs and Giles 1832). A 1929 plat of the area shows the property (Block 72) included in San Antonio Suburban Irrigated Farms subdivision (BCDR Vol. 980:215). Lots that makeup the project area are one (1), two (2) and portions of Lot three (3) and Lot six (6) (BCAD 2008). The recorded structure is located in Lot one (1).

Land deed records that correspond to the said time frame of the structure began in 1922 when the San Antonio Southern Railway Co. conveyed land out of the A. Bustillos State Abstract no. 52 to Harry Landa (BCDR Vol. 699:163). Neither block numbers nor lots were mentioned in this deed only that all those certain tracts or parcels of land described as "a strip of land beginning in MacDona, Bexar County and running in a southerly direction to the town of Kirk". A 1942 USGS of West San Antonio, Texas shows the community of Kirk near the project area (Figure 3-2). In March of 1928, the land was granted to the San Antonio Suburban Irrigated Farms by Harry Landa (BCDR Vol.1005:511). In October of

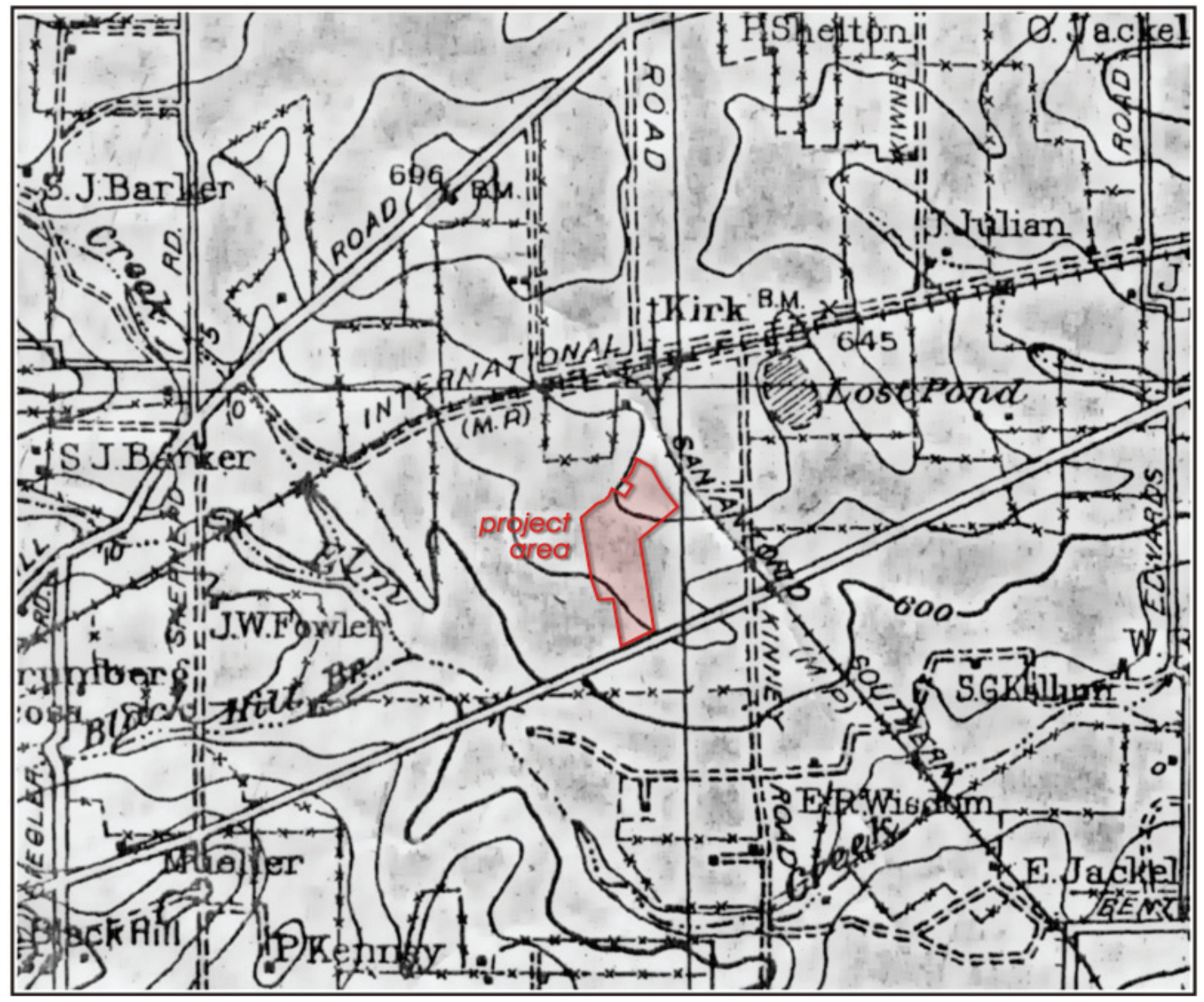

Figure 3-2. 1942 USGS quadrangle map of West San Antonio, Texas. 
1928 the San Antonio Suburban Irrigated Farms conveyed the land to the Wheeler Kelly Hagney Trust Company (BCDR Vol.1064:606). Again neither blocks nor lots were mentioned in the land deeds from 1922 to 1928 when the land was granted to the Wheeler Kelly Hagney Trust Company.

Wheeler Kelly granted Lots two (2) and three (3) to A.W. Cooper in 1935 (BCDR Vol 1631:340). In 1935 Medina Irrigated Farms granted portions of Lots two (2) and six (6) to A.W. Cooper (BCDR Vol 1475:603; Vol. 1487:560) in two separate deeds. Also, in 1935, Medina Irrigated Farms conveyed portions of Lot six (6) to Mamie Steele Jarratt (BCDR Vol 1481:237). Jarratt Road is located north of the project area where it merges with Herring Road. Jarratt Road at one time crossed the northern portion of the project area just along Lot 1 .

In 1943 the Wheeler Kelly and Hagney Investment Company granted Lots one (1) and three (3) to Paul and Tillie Castiglione (BCDR Vol. 1977:424). Lots one (1) and three (3) were conveyed to Vito Castiglione in February of 1950 (BCDR Vol.2831:480). In April of 1950 A.W. Cooper was granted Lot one (1) and portions of Lot three (3) by Vito Castiglione (BCDR Vol.2831:480). Jarratt Road is mentioned in the land descriptions of Lot one (1) and Lot three (3).

Richard C. Aldridge, Jr. and Meredith Aldridge obtained Lots one (1), two (2), three (3) and six (6) in 1957 from A.W. Cooper (BCDR Vol.3889:31). Aldridge founded the Aldridge Nursery in 1939. The structure associated with 41BX1790 is not mentioned until 1991 when the property was leased (BCDR Vol.5132:658). The most recent transaction of the land that was documented was in 2007 (BCDR Vol. 13317:1942).

\section{Medina Lake Irrigation Canals}

Several canals are depicted on the 1929 plat, along the western and southeastern portions of the APE. Canal B or sometimes referred to as Canal B-77 is mentioned in almost all of the deed records summarized in the project area land history section.
The canal is part of the Medina Lake Irrigation Canals (Figure 3-3). Medina Lake was constructed between 1911 and 1912 for the purposes of an irrigation reservoir for an extensive canal system (Eckhardt 2008). In 1910, engineer Dr. Fred Stark Pearson swayed British investors to finance the construction of the Medina dam and the canal system (Eckhardt 2008). The endeavor took a crew of 1,500 men. Stark is credited with building the dam but Henri Castro, the founder of Castroville, envisioned such as system around 1850 (Eckhardt 2008). Unfortunately, the means to construct the system were not available at the time.

The 97 year old system belongs to the Bexar-MedinaAtascosa Counties Water Control and Improvement District 1. The water from the irrigation canals supplies water to about 33,000 acres of farmland in the Medina River Valley (Slattery and Miller 2004). The water is diverted near Medina Lake and delivered through the irrigation system that runs 57 miles along the main canal and then over 230 miles of smaller laterals and ditches (Sierra Club 2005).

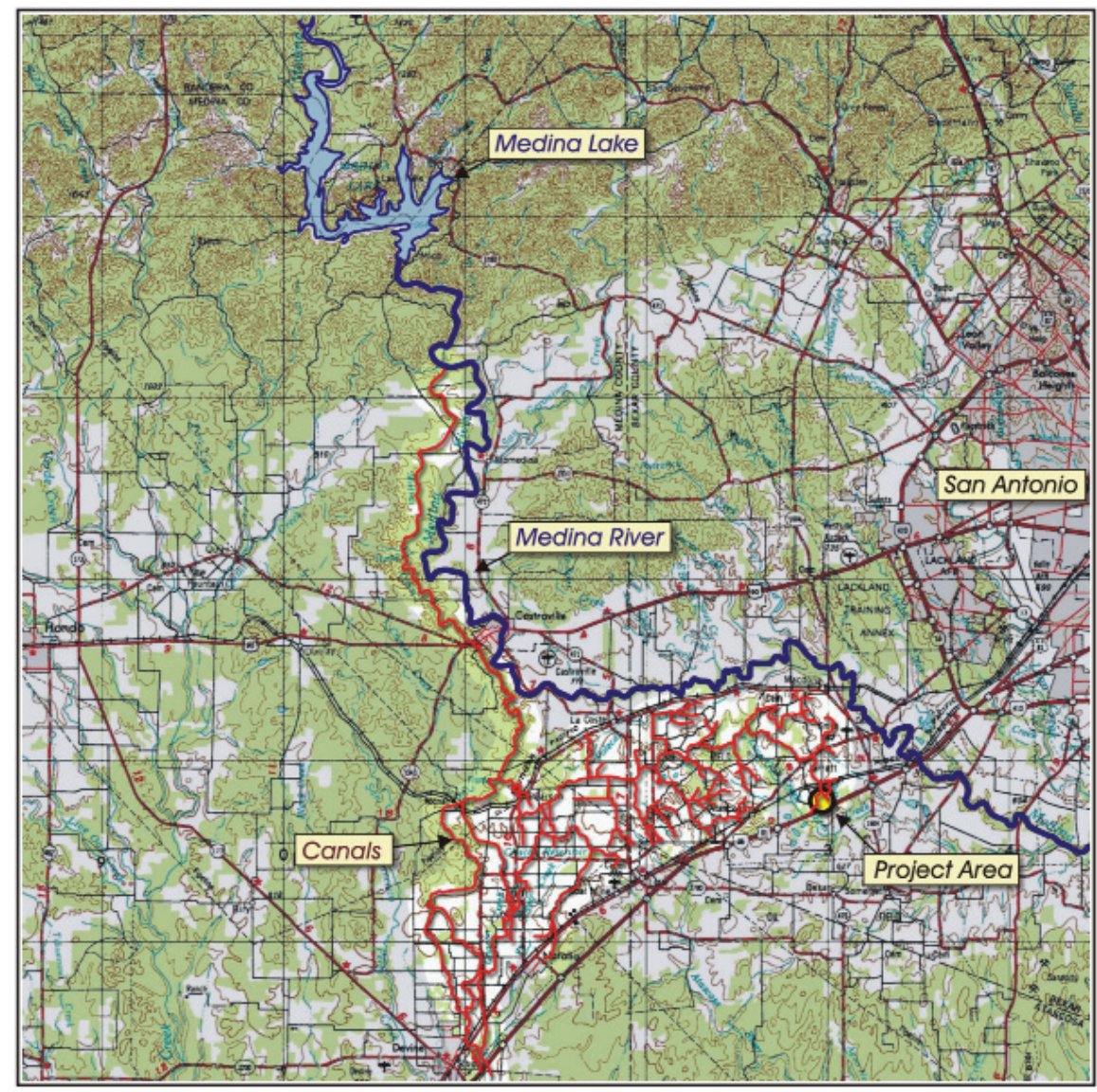

Figure 3-3. Medina Lake irrigation canals. 



\section{Chapter 4: Field and Laboratory Methods}

\section{Shovel Tests}

According to the Minimum Survey Standards put forth by the Texas Historical Commission, a pedestrian survey of approximately 59.291 acres minimally requires a shovel test every 2 acres ( 30 shovel tests). The project area was traversed by CAR field crew on transects spaced 30 meters apart. CAR excavated shovel tests across the project area in settings with a potential for buried cultural materials when there is less than 30 percent ground visibility. In some cases, the location of the shovel tests was omitted due to flooding and construction disturbance. All shovel tests were $30 \mathrm{~cm}$ in diameter and excavated to a depth of 60 centimeters below surface (cmbs) in 10 -cm levels. Soils were screened through .25 in. mesh. CAR crews recorded the location of all excavated shovel tests with Trimble GPS unit and the project archaeologist plotted their locations on an aerial map of the project area. A shovel test form was completed for each shovel test and included observations of soil texture and color, artifact counts and depth, excavation depth of the shovel test, and other surveyor notes.

Shovel tests that contained cultural material at least 50 years old and therefore represent either historic or prehistoric components were identified as positive shovel tests. Upon excavation of a positive shovel test, additional shovel tests were dug at decreased intervals $15 \mathrm{~m}$ in each cardinal direction from the original test in order to determine whether a site was present and to define the site boundaries if it met the site definition (discussed below). Additional shovel tests were excavated until no cultural materials are recovered in two consecutive tests.

All artifacts and samples collected from the field were analyzed and processed in the CAR laboratory. Photographs and paperwork generated during this project were prepared by the CAR lab for permanent curation.

\section{Documenting New Sites}

During the archaeological survey new sites were defined as follows: 1) locations with at least five artifacts within a 30 $\mathrm{m} 2$ area or; 2) a location containing a single cultural feature such as a hearth, either on surface or exposed in a shovel test or; 3) a location with a positive shovel test containing at least three artifacts within a given $10-\mathrm{cm}$ level or; 4) a location with a positive shovel test containing at least five total artifacts or; 5) two positive shovel tests located within 30 $\mathrm{m}$ of each other. All surface artifacts or positive shovel tests that do not meet the site definitions presented above were classified as isolated finds. Between six and eight shovel tests were excavated to define a site's boundary within the project area. Standardized site forms with observations about artifact distribution, vegetation, artifact densities, and features were completed. In addition, sketch maps showing site boundaries, datum locations, shovel tests, collected items, archaeological features and physical features of the landscape were drawn. The site boundary, datum, shovel tests, and other landmarks within or near the site such as standing structures, creeks, or fences were collected with a GPS. Site forms were prepared for all newly documented sites using standard forms and sites were recorded in the Texas Archeological Sites Atlas database and a trinomial was requested.

\section{Laboratory Methods}

All cultural material collected during the survey was prepared in accordance with federal regulation 36 CFR part 79 and in accordance with current guidelines of the Center for Archaeological Research. Artifacts were processed in the CAR laboratory where they were washed, air-dried, and stored in archival-quality bags. Artifacts were sorted into appropriate analytical categories. Acid-free labels were placed in all artifact bags. Each label displayed provenience information and a corresponding lot number laser printed or written in pencil. Artifacts were separated by class and stored in acid-free boxes identified with standard labels. The data was entered into a Microsoft Access database. All artifacts are permanently curated at CAR. Field notes, forms, and hard copies of photographs were placed in labeled archival folders. All field forms were completed in pencil. Documents and forms were printed on acid-free paper and any soiled forms will be placed in archival-quality page protectors. A copy of the final report in Adobe Acrobat ${ }^{\circledR}$ file format and all digital material pertaining to the project, including photographs, were burned onto a CD and permanently curated with the field notes and documents at the Center for Archaeological Research. 



\section{Chapter 5: Results of the Archaeological Investigations}

CAR conducted the pedestrian survey of 60 acres associated with the planned First Responders Academy in southwest Bexar County between November 19-21, 2008. During the survey, 34 shovel tests were excavated and two new sites, 41BX1789 and 41BX1790, were identified and recorded by the CAR field crew (Figure 5-1). 41BX1789 is a multi- component site with a historic structure, trash dump and one piece of prehistoric lithic debitage. Two positive shovel tests containing lithic debitage and fire-cracked rock defined prehistoric site 41BX1790. CAR does not recommend either site as eligible for NRHP listing or formal designation as State Archeological Landmark (SAL). This

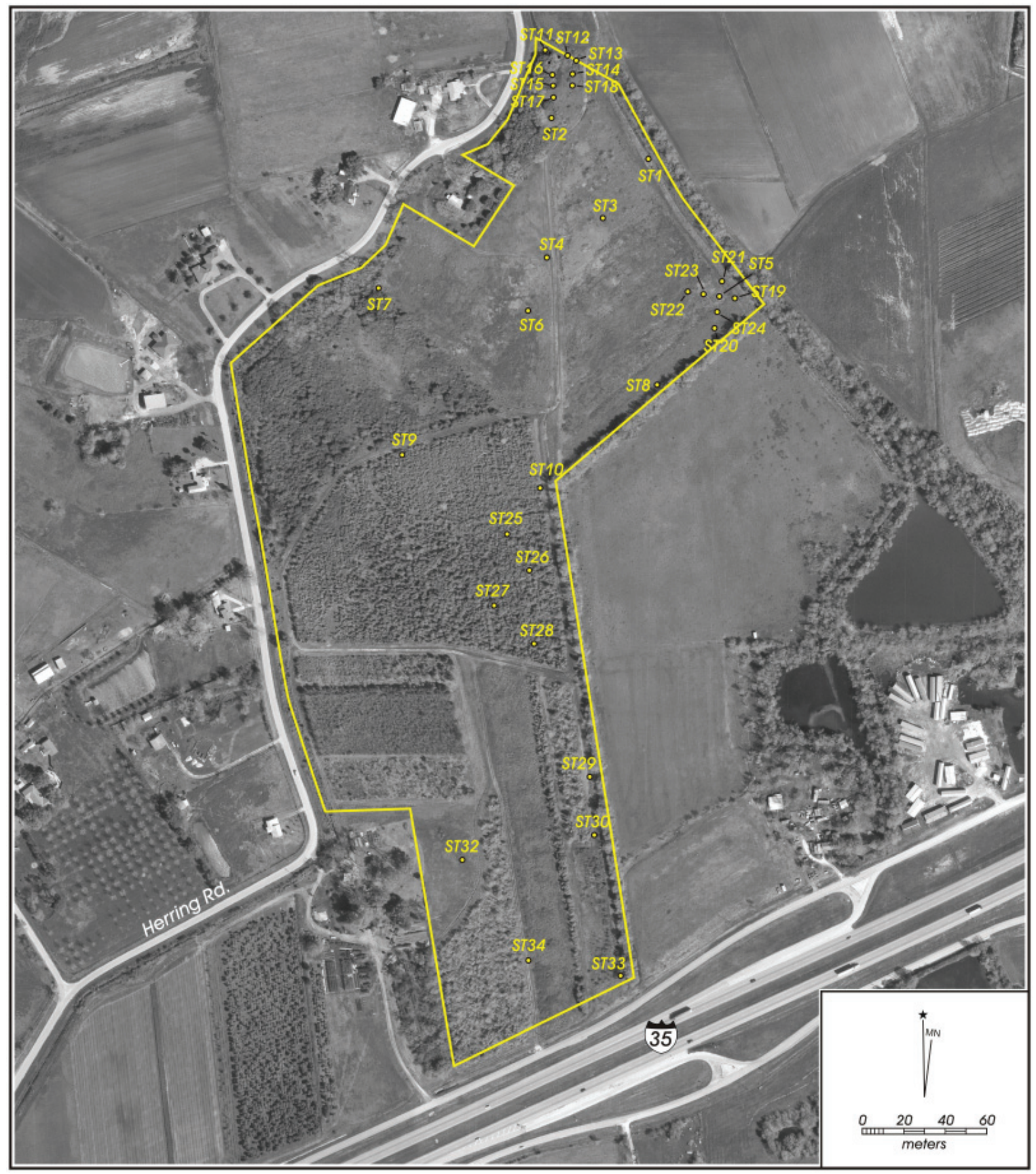

Figure 5-1. Aerial photograph of the project area depicting shovel tests. 
chapter presents the results of the archaeological survey performed by CAR.

Approximately 10 acres $(6 \%)$ of project area has been disturbed by the preliminary construction related to the facilities of the First Responders Academy. Preliminary construction activities include a paved parking lot, temporary building, concrete slabs and grading of the ground surface (Figures 5-2).

The northern portion of the project area is an open field that has been disturbed by agricultural and land clearing activities. Other disturbances to the APE have been caused by tree extraction associated with the Aldridge Nursery that once owned the property. Holes at least 2 meters in diameter and 0.5 to 1 meter deep were visible in the central portion of the project area and on the margins of the south-central and southwestern portions as well (Figure 5-3). The area is dominated by Red Oak and one bundled tree was observed that was not removed (Figure 5-4).The canal along the western and northern boundaries and related drainages have caused inundation of the eastern portions of the project area. Disturbed and inundated areas were not subject to shovel testing.

\section{Shovel Tests}

Thirty-four shovel tests were excavated as part of the pedestrian survey. Shovel tests were excavated along transects that were spaced 30 meters apart and were oriented east-west. Two new sites were identified and recorded as a result of the archaeological investigations. Several portions of the APE have been disturbed, eliminating the need for shovel testing in those areas.

Transects began at the northern end of the APE oriented east-west. The northern portion of the APE is an open agricultural field that has been disturbed by agricultural activities. The soils in the first $30 \mathrm{~cm}$ of the shovel tests appeared to be associated with a plow zone and consisted of blocky clay. The soil became less blocky below the upper $30 \mathrm{~cm}$ of dark brown blocky clay. Soil colors in the northern portion of the APE ranged from a brown (10 YR 3/3) to a reddish brown (5 YR 4/4). Three positive tests were located in the northern portion of the APE associated with 41BX1789 and 41BX1790 (Table $5-1$ ). Wet soils in the west-central portion of the project area prevented one shovel test from reaching $60 \mathrm{cmbs}$. In the central and southern portion of the APE many areas were disturbed by extraction of Red Oak trees by Aldridge Nursery and inundation by drainages associated with the canal that runs outside the property. Two dirt roads that traverse this portion of the project area and the preliminary construction
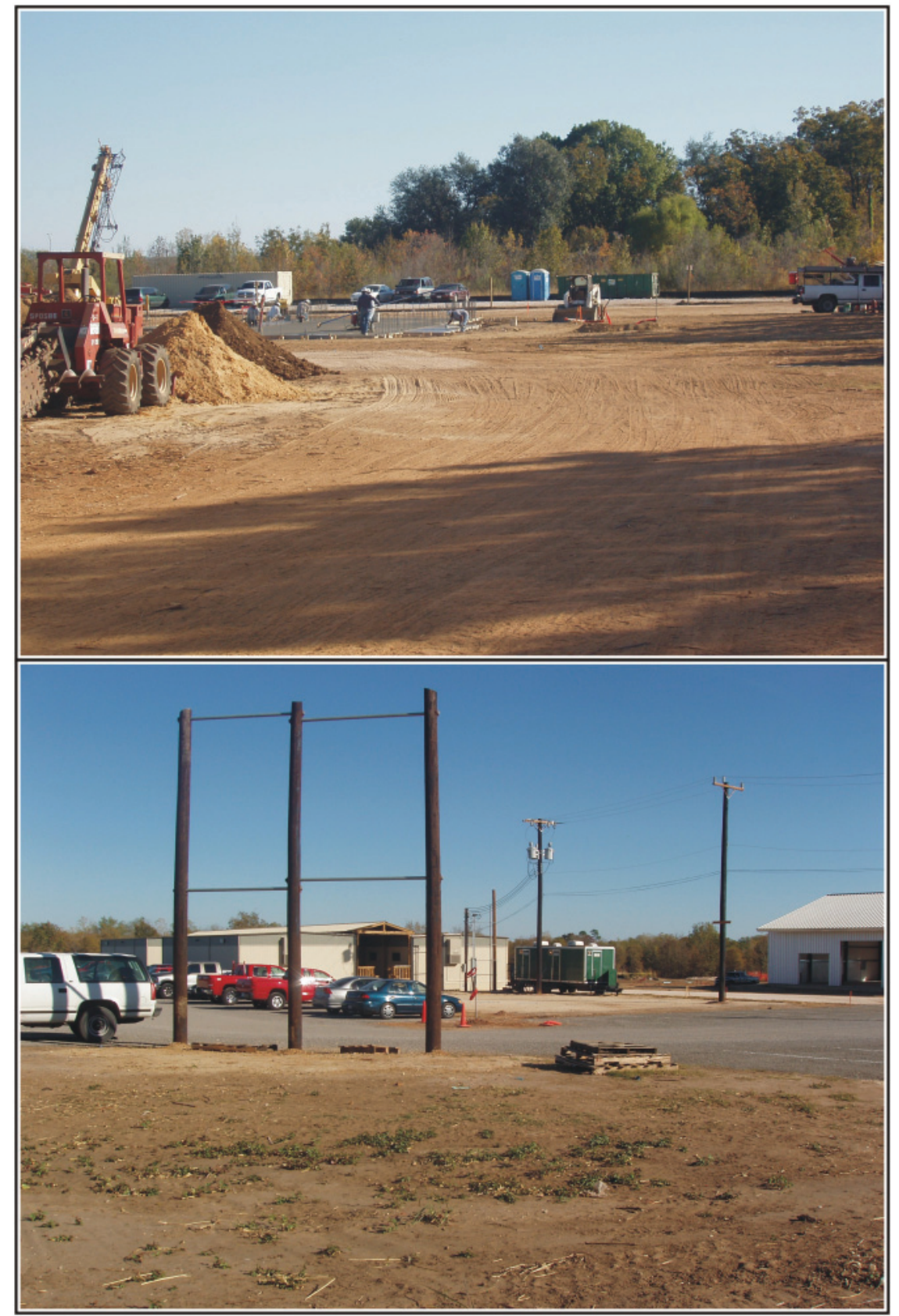

Figure 5-2. Impacts from preliminary construction of the First Responders Academy. 


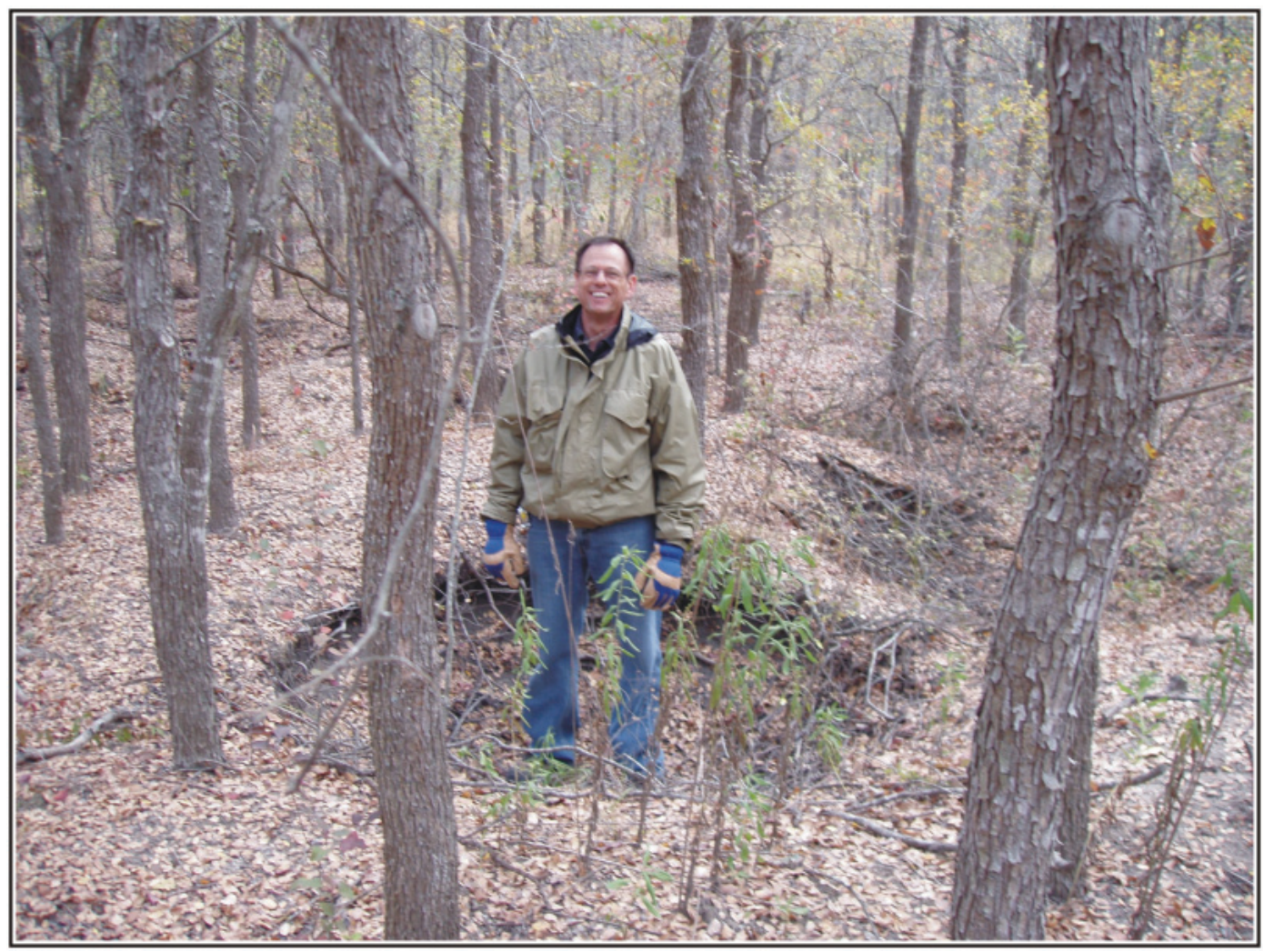

Figure 5-3. Area that has been disturbed by tree removal.

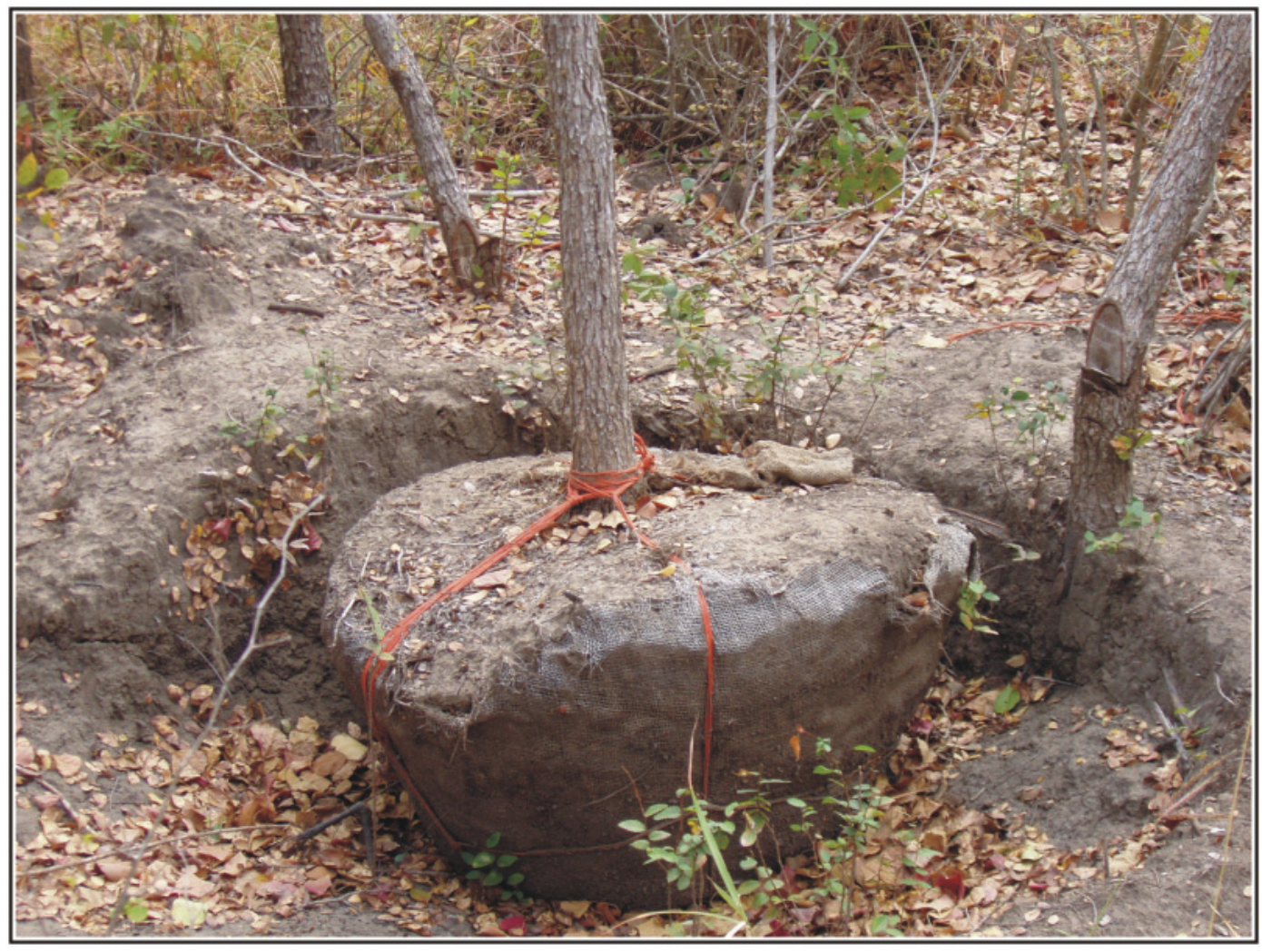

Figure 5-4. Bundled tree left from Aldridge Nursery. 
Table 5-1. Shovel Test Results

\begin{tabular}{|c|c|c|}
\hline $\begin{array}{c}\text { Shovel } \\
\text { Test }\end{array}$ & $\begin{array}{l}\text { Terminal Depth } \\
\text { (cmbs) }\end{array}$ & Results \\
\hline 1 & 60 & negative \\
\hline 2 & 60 & negative \\
\hline 3 & 60 & negative \\
\hline 4 & 60 & negative \\
\hline 5 & 60 & positive \\
\hline 6 & 60 & negative \\
\hline 7 & 54 & negative \\
\hline 8 & 60 & negative \\
\hline 9 & 60 & negative \\
\hline 10 & 60 & negative \\
\hline 11 & 60 & negative \\
\hline 12 & 60 & negative \\
\hline 13 & 60 & negative \\
\hline 14 & 60 & negative \\
\hline 15 & 60 & positive \\
\hline 16 & 60 & negative \\
\hline 17 & 60 & negative \\
\hline 18 & 60 & negative \\
\hline 19 & 60 & negative \\
\hline 20 & 60 & positive \\
\hline 21 & 60 & negative \\
\hline 22 & 60 & negative \\
\hline 23 & 60 & negative \\
\hline 24 & 60 & negative \\
\hline 25 & 60 & negative \\
\hline 26 & 60 & negative \\
\hline 27 & 60 & negative \\
\hline 28 & 60 & negative \\
\hline 29 & 60 & negative \\
\hline 30 & 60 & negative \\
\hline 31 & 60 & negative \\
\hline 32 & 60 & negative \\
\hline 33 & 60 & negative \\
\hline 34 & 60 & negative \\
\hline
\end{tabular}

of the First Responders facilities in the southwestern portion of the project area add further disturbance to the project area. Shovel tests in these areas revealed brown (10YR 4/3) compacted clay loam.

\section{BX1789}

This site is located in the northern portion of the APE, just east of Herring Road on the fringes of an agricultural field.
The site is bound by a irrigation canal to the west and north. The principal feature of the site is a two room wooden structure with attached bathroom/shed to the north of the main structure (Figure 5-5). The main entry of the house faces to the west and consists of a wooden framed doorway flanked by two double hung sash windows (Figure 5-6). The roof and walls consist of standing seam metal. Figure 5-7 shows the east room of the house with exposed metal wall and wooden frame. The attached structure consists of an interior bathroom that contains a shower stall and commode and an exterior space with a metal roof overhang where the water heater was stored (Figure 5-8).

During CAR's investigation of the site, asbestos tile was in the process of being removed from the structure. A pile of debris containing ceramics, metal, glass and a couple of wooden beams were located about 12 meters south of the structure (Figure 5-9). The debris pile could be remnants of a former outbuilding associated with the standing structure.

The Bexar County Appraisal District (BCDR 2008) lists a 1930 construction date for the structure and addition. After a deed search of the Bexar County records, only one deed of the land from 1991 mentioned the two room structure (BCDR 15:673). If the appraisal district records are correct and the structure was built in the 1930s, the land would have been in the hands of Wheeler Kelly. However, considering that the structure is never mentioned in deed transactions between Wheeler Kelly and Castiglione in 1943 it is not likely that it was constructed when Wheeler Kelly owned the land. The only mention of the structure is in a 1991 lease agreement. It seems the structure would have been constructed during the time that Richard C. Aldridge owned the property, beginning in 1957.

Eight shovel tests were excavated to determine the site boundaries. Only one shovel test (Shovel Test 15), out of eight excavated around the site was positive for cultural material (Table 5-2). Cultural material from Shovel Test 15 consisted of cermic, debitage $(n=1)$ and metal. A sample of artifacts was collected from the debris pile and is listed in Table 5-2. Diagnostic materials collected from the debris pile included ceramics with maker's marks $(n=2)$. A partial porcelain Cameo Rose-American plate was collected. The ware was made from 1955 to 1970 (Flickr 2008). A semi-porcelain plate fragment exhibiting an Edward Knowles markers mark was also collected. This ware dates from 1900 to 1948 (Gates and Ormerod 1982:99). With the exception of the single piece of debitage from Level 2 of ST 15, no other prehistoric artifacts were found at the site. 


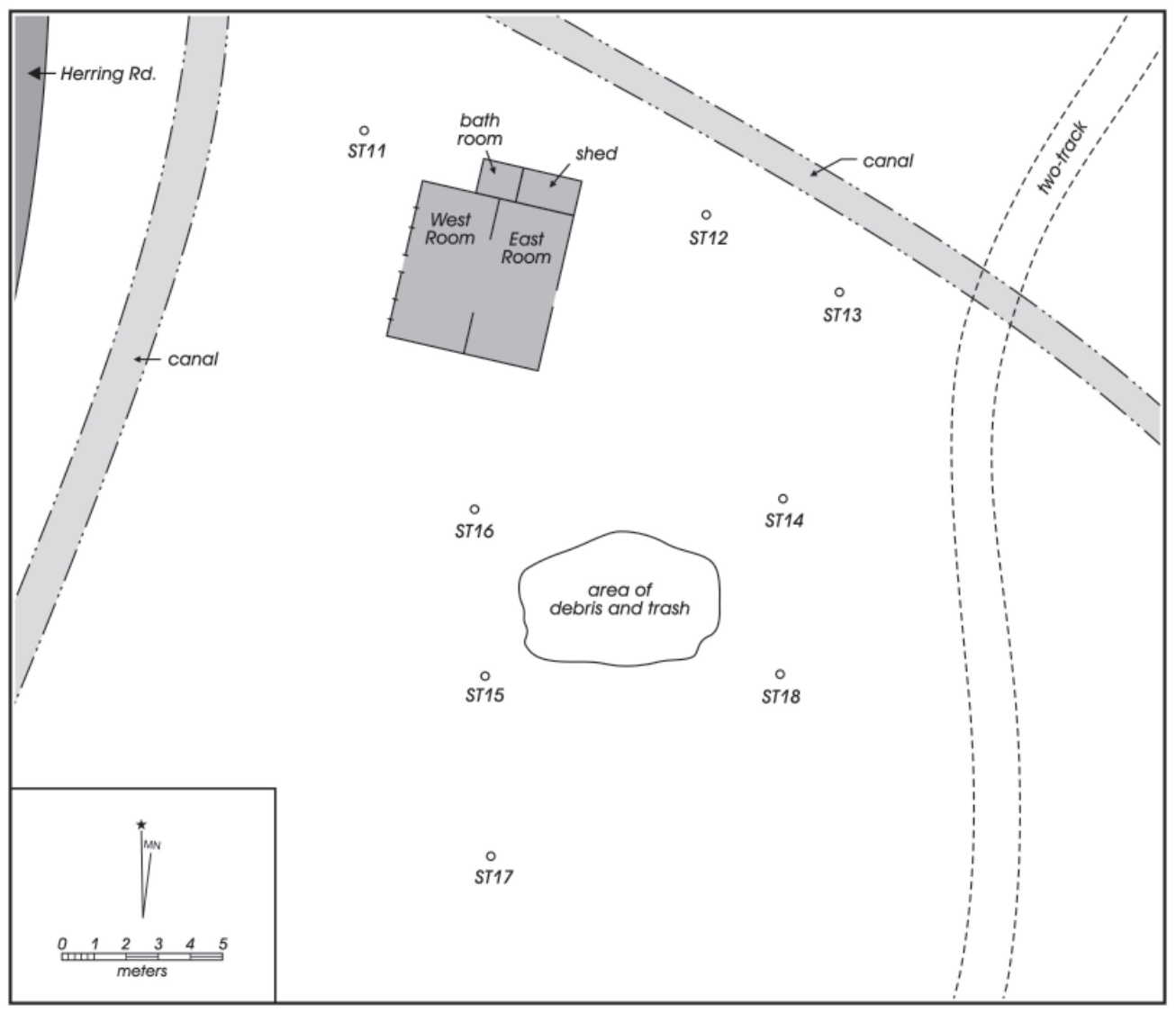

Figure 5-5. Sketch map of $41 B X 1789$.

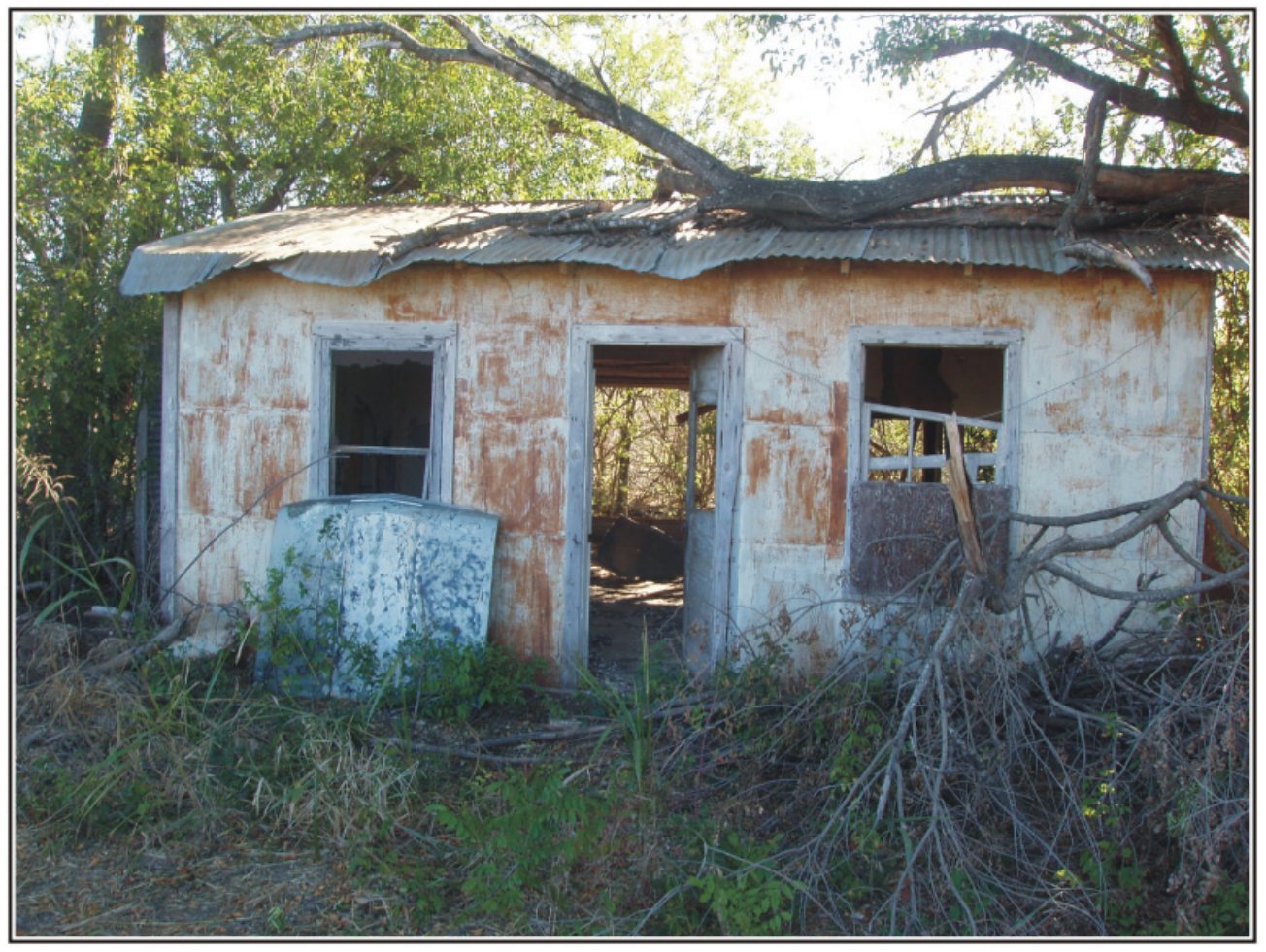

Figure 5-6. Two room structure at $41 B X 1789$ (facing east). 


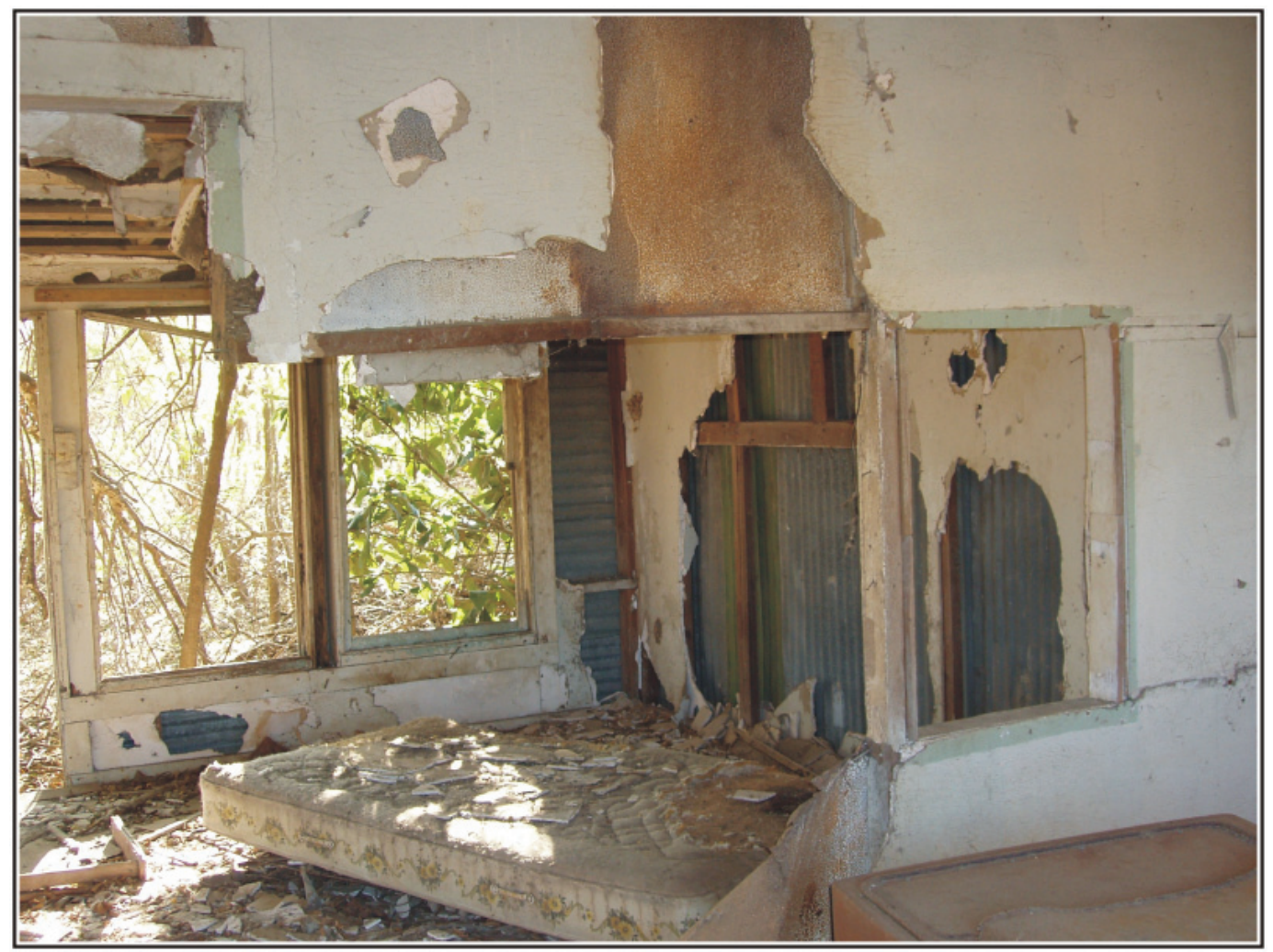

Figure 5-7. East room of structure at 41BX1789, note exposed metal walls and wooden frame (facing southeast).

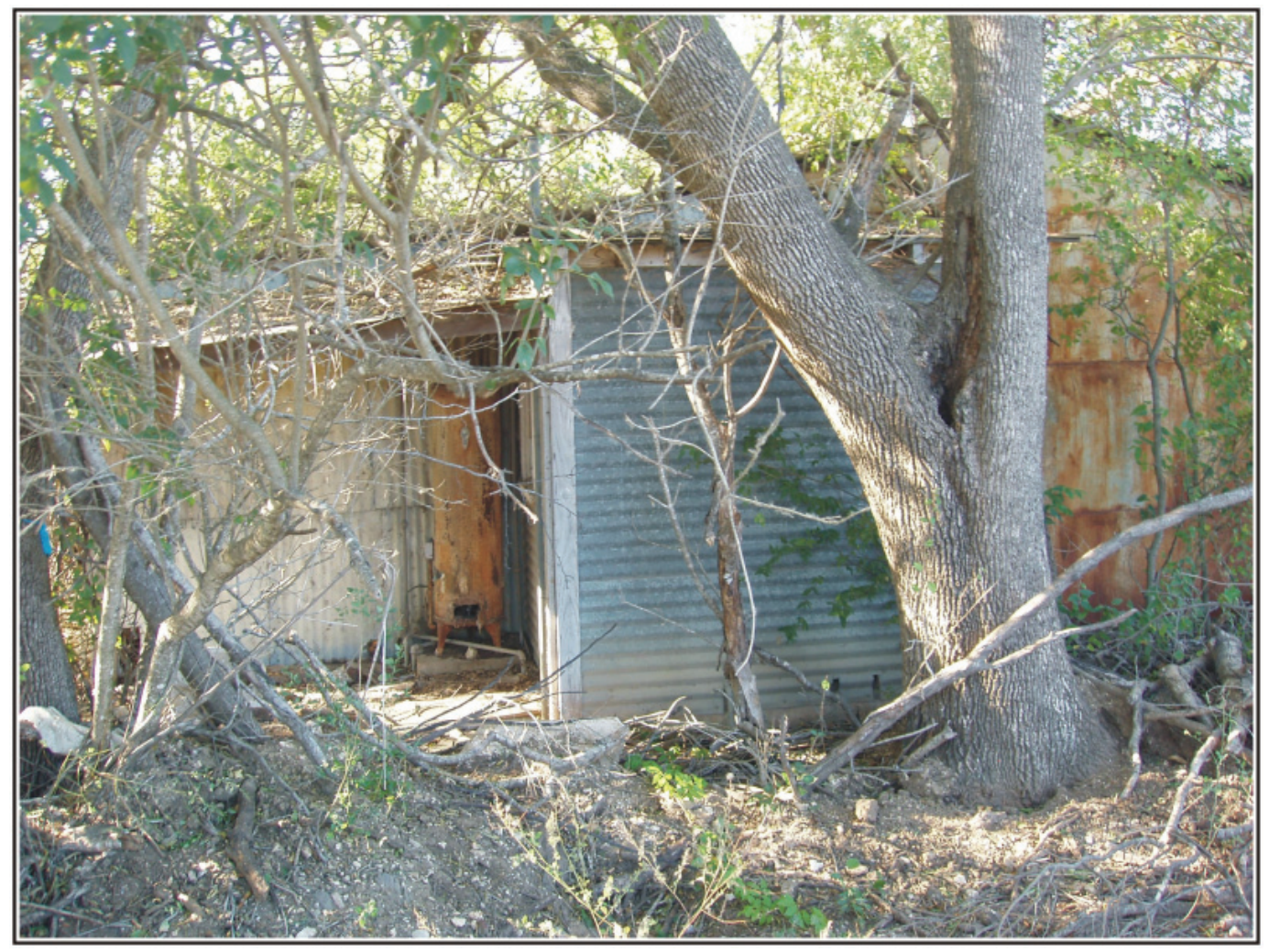

Figure 5-8. North façade of structure at $41 B X 1789$ with attached bathroom and open shed. 


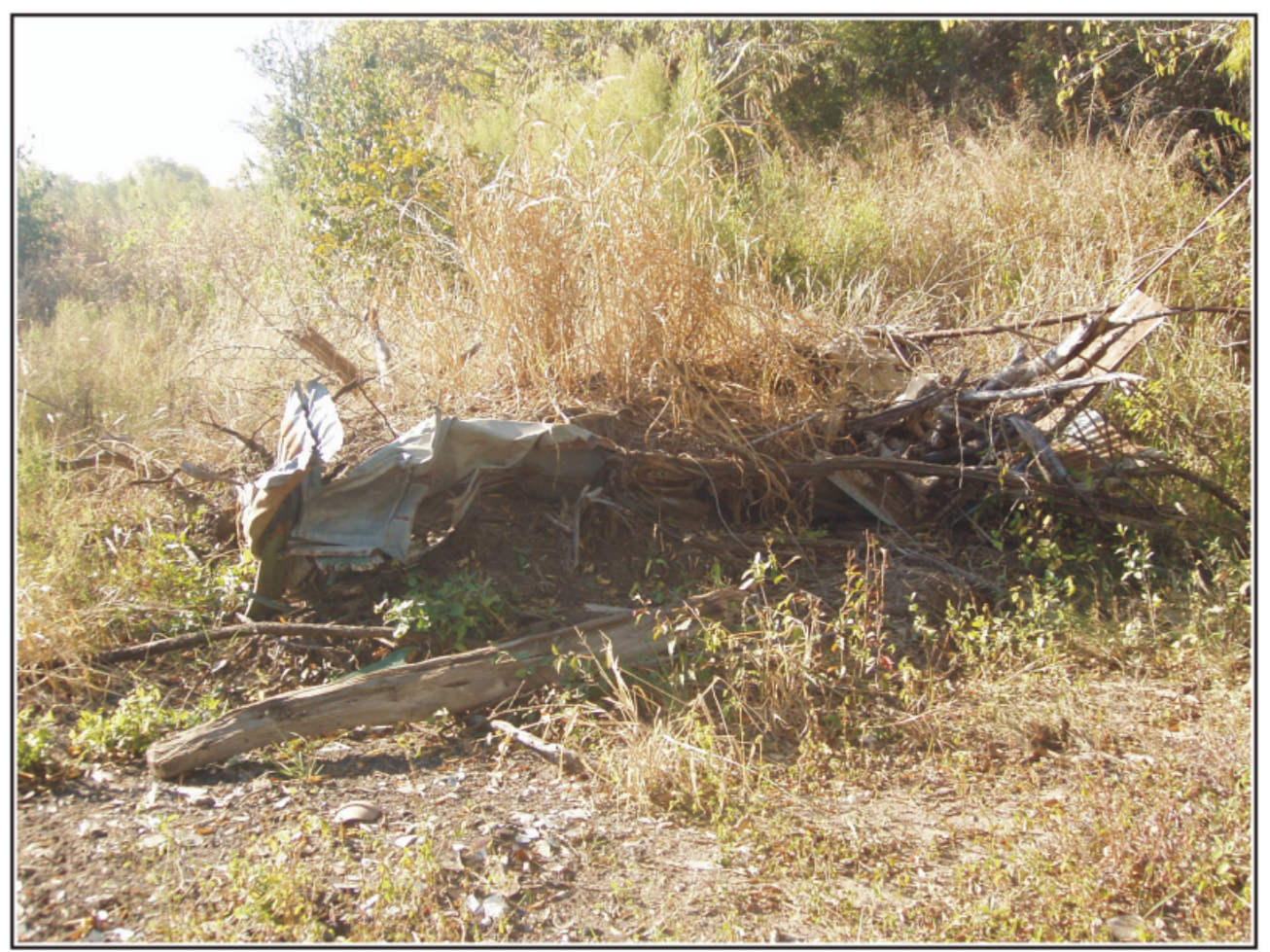

Figure 5-9. Debris pile south of structure containing wooden beams, glass, metal and ceramics.

Table 5-2. Cultural Material from 41BX1789 and 41BX1790

\begin{tabular}{|c|c|c|c|c|c|c|c|c|c|}
\hline Site & $\begin{array}{c}\text { Shovel } \\
\text { Test }\end{array}$ & Level & $\begin{array}{c}\text { Burned } \\
\text { Rock }\end{array}$ & Ceramics & Debitage & Glass & Metal & Other & $\begin{array}{c}\text { Grand } \\
\text { Total }\end{array}$ \\
\hline \multirow{5}{*}{ 41BX1789 } & \multirow{4}{*}{15} & 1 & 0 & 1 & 0 & 0 & 1 & 0 & 2 \\
\hline & & 2 & 0 & 0 & 1 & 0 & 1 & 0 & 2 \\
\hline & & 3 & 0 & 0 & 0 & 0 & 1 & 0 & 1 \\
\hline & & 4 & 0 & 0 & 0 & 0 & 1 & 0 & 1 \\
\hline & Surface & 0 & 0 & 10 & 0 & 5 & 2 & 1 & 18 \\
\hline \multicolumn{3}{|c|}{ 41BX1789 Total } & 0 & 11 & 1 & 5 & 2 & 1 & 20 \\
\hline \multirow{2}{*}{ 41BX1790 } & 20 & 1 & 1 & 0 & 1 & 0 & 0 & 0 & 2 \\
\hline & 5 & 1 & 0 & 0 & 1 & 0 & 0 & 0 & 1 \\
\hline \multicolumn{3}{|c|}{ 41BX1790 Total } & 1 & 0 & 2 & 0 & 0 & 0 & 3 \\
\hline
\end{tabular}

Disturbance was evident on the site in the form of push piles and tire ruts to the north and south. Given the information obtained from the deed research and cultural material the structure dates to the early 1950 s. Due to the poor integrity of the structure and the lack of intact deposits we do not recommend the site eligible for listing in the NRHP or SAL.

\section{BX1790}

41BX1790 is located in the northeast portion of the APE in an open agricultural field. The site is bound by a fence line to the east and south. Six shovel tests were excavated to determine site limits but only Shovel Tests 5 and 20 were positive for material in the first $10 \mathrm{~cm}$ level (Table 5-1). The site is defined as a prehistoric site with the presence of debitage $(\mathrm{n}=2)$ and burned rock $(n=1)$ in two shovel tests within 30 meters of each other. Soils associated with the site consist of a reddish brown (5 YR 4/4) hard blocky clay.

The site has been affected by erosion accelerated by agricultural use of the land. Further work is not recommended on the site and it is not eligible for listing to the NRHP or formal designation as an as an SAL. 


\section{Summary}

During the survey conducted by CAR, 34 shovel tests were excavated across the 60 acre tract and two sites were recorded. Historic site 41BX1789 consisted of a 1950s two room structure and associated surface debris. Deed research indicates the structure was built while the property was owned by the Aldridge Nursery. 41BX1780 consisted of a light scatter of debitage and burned rock. CAR does not recommend further work at either site. The project area has been disturbed by preliminary construction of the First Responders Academy and tree removal associated with the Aldridge Nursery that once occupied the land. The historic canal that runs along the north and western perimeters of the project area has flooded into the western margins of the area. 


\section{Chapter 6: Conclusions and Recommendations}

During November 2008, CAR-UTSA conducted archaeological investigations for the planned First Responders Academy located in southeast Bexar County, Texas. As a result of the survey 34 shovel tests were excavated and two sites were documented. Construction, tree removal and inundation have disturbed portions of the APE.

During the course of the project, two sites were recorded. 41BX1789 is historic site that consists of a historic structure and debris and a single piece of debitage. The structure dates to the early 1950s and was probably built when the property was in the hands of the Aldridge Nursery. CAR does not recommend the site eligible for listing as a NRHP or designation as a SAL. 41BX1790 was identified as a prehistoric site and contained little cultural material $(n=3)$ in two shovel tests, within 30 meters of each other. CAR does not recommend the site for listing in the NRHP or for designation as a SAL. Further work is not recommended on either site and proposed construction can proceed as planned. 



\section{References Cited}

Bauer, J.

1974 The Mexican War, 1846-1848. Macmillan, New York.

Bement, L.C.

1989 Excavations at 41BP19: The Kennedy Bluffs Site, Bastrop County, Texas. Texas Archaeological Research Laboratory, The University of Texas at Austin. Contract Reports in Archaeology, Report No. 5, Highway Design Division, Texas State Department of Highways and Public Transportation, Austin.

Bexar County Archives (BCA)

1809 The Pita Road to Monclova, Mexico. Micro film roll 41, \#0509-510-511.

Bexar County Appraisal District (BCAD)

2008 http://www.bcad.org/. Accessed December 15, 2008.

Bexar County Deed Records (BCDR)

2008 http://www.countyclerk.bexar.landata.com/. Accessed December 15, 2008.

Black, S.L. and D.G. Creel

1997 The Central Texas Burned Rock Midden Reconsidered. In Hot Rock Cooking on the Greater Edwards Plateau: Four Burned Rock Midden Sites in West Central Texas, by Steve Black, Linda W. Ellis, Darrell G. Creel, and Glenn T. Goode, pp.269-305. Studies in Archeology 2. Texas Archeological Research Laboratory, The University of Texas at Austin.

Boggs, W.K. and J.B. Giles

1932 Original Survey No. 56, Map of Bexar County. The General Land Office, Austin.

Bomar, G.

1999 Texas Weather. The University of Texas Press, Austin.

Buckley, E.C.

1991 The Aguayo Expedition into Texas and Louisiana, 1719-1722. Quarterly of the Texas State Historical Association $\mathrm{XV}(1): 1-65$

Buerkle, R.C.

1976 The Continuing Military Presence. In San Antonio in the 18th Century. San Antonio Bicentennial Heritage Committee.

Chipman, D.E.

1992 Spanish Texas, 1519-1821. The University of Texas Press, Austin.

Collins, M.B.

1995 Forty Years of Archeology in Texas. Bulletin of the Texas Archeological Society 66:361-400.

Cox, I.W.

2005 Appendix D: History of the "Priest's House" on Military Plaza. In Test Excavations and Monitoring at 41BX1598: A Multicomponent Historic Site in Bexar County, Texas. Archaeological Report, No. 360. Center for Archaeological Research, The University of Texas at San Antonio. 
Eckhardt, G.

2008 Medina Lake and Canal System. The Edwards Aquifer Website. http://www.edwardsaquifer.net/media.htm. Accessed December 2008.

Flickr

2008 Cameo Rose-American Dinnerware. http://flickr.com/photo/charlesanthony61/85537851/in/pool/. Accessed December $10,2008$.

Fox, A.A.

1997 Test Excavations at the Spanish Governor's Palace, San Antonio, Texas. Archaeological Survey Report, No. 259. The Center for Archaeological Research, The University of Texas at San Antonio.

Fox, A.A., M. Renner, and R.J. Hard

1997 Archaeology at the Alamodome: Investigations of a San Antonio Neighborhood in Transition, Volume III: Artifacts and Special Studies. Archaeological Survey Report, No. 238. Center for Archaeological Research, The University of Texas at San Antonio.

Fox, A.A. and I.W. Cox

2000 Archaeological Monitoring for Exterior Lighting and Test Excavations at Mission San Juan Capistrano, Bexar County, Texas. Letter Report, No. 131. Center for Archaeological Research, The University of Texas at San Antonio.

Gates, W.C., Jr., and D. Ormerod

1982 The East Liverpool Pottery District: Identification of Manufacturers and Marks. Historical Archaeology 16(1/2).

Hall, G.D., T.R. Hester, and S.L. Black

1986 The Prehistoric Sites at Choke Canyon Reservoir, Southern Texas: Results of the Phase II Archaeological Investigations. Choke Canyon Series, No. 10. Center for Archaeological Research, The University of Texas at San Antonio.

Hester, T.R.

1995 The Prehistory of South Texas. Bulletin of the Texas Archeological Society 66:427-459.

Hoffman, F.L. (translator)

1937 Diary of the Alarcón Expedition into Texas, 1718-1719. Quivira Society Publications Volume 45:39.

Inman, B.J., T.C. Hill, Jr., and T.R. Hester

1998 Archeological Investigations at the Tortugas Flat Site, 41ZV155, Southern Texas. Bulletin of Texas Archeological Society 69:11-33.

Jackson, J.

1986 Los Mestenos: Spanish Ranching in Texas, 1721-1821. Texas A\&M University Press, College Station.

Long, $\mathrm{C}$

2008 Von Ormy, Texas. http://www.tshalonline.org/handbook/online/articles/VV/htv9.html. Accessed December 4, 2008.

Mauldin, R.P., D.L. Nickels, and C.J. Broehm

2003 Archaeological Testing to Determine the National Register Eligibility Status of 18 Prehistoric Sites on Camp Bowie, Brown County, Texas. Archaeological Survey Report, No. 334. Center for Archaeological Research, The University of Texas at San Antonio. 
Mauldin, R.P., B.K. Moses, R.D. Greaves, S.A. Tomka, J.P. Dering and J.D. Weston

2004 Archeological Survey and Testing of Selected Prehistoric Sites along FM 48, Zavala County, Texas. Archaeological Survey Report, No. 352, Center for Archaeological Research, The University of Texas at San Antonio, and Archeological Studies Program, Report No. 67, Environmental Affairs Division, Texas Department of Transportation, Austin.

Mauldin, R.P. and L. Kemp

2005 An Initial Summary of Bison Presence/Absence associated with Data Recovery at 41ZV202. Report on file at the Center for Archaeological Research, The University of Texas at San Antonio.

Mauldin, R.P., J.L. Thompson, and L. Kemp

2006 Bison, Bowls, and Bunnies. Paper presented at the 82nd Society for American Archaeology Annual Meeting, Austin.

McGraw, J.A. and K. Hindes

1987 Chipped Stone and Adobe: A Cultural Resources Assessment of the Proposed Applewhite Reservoir, Bexar County, Texas. Archaeological Survey Report, No. 163. The Center for Archaeological Research, The University of Texas at San Antonio.

McGraw, A.J, J.W. Clark, Jr., E.A. Robbins

1998 A Texas Legacy The Old San Antonio Road and The Caminos Reales: A Tricentennial History, 1691-1991. Texas Department of Transportation, Austin.

McKinney, W.W.

1981 Early Holocene Adaptations in Central and Southern Texas: The Problem of the Paleoindian-Archaic Transition. Bulletin of the Texas Archaeological Society 52:91-120.

Meltzer, D.J. and M.R. Bever

1995 Paleoindians of Texas: An Update on the Texas Clovis Fluted Point Survey. Bulletin of the Texas Archeological Society 66:47-81.

Moorehead, M.

1991 The Presidio: Bastion of the Spanish Borderlands. University of Oklahoma Press, Norman.

Nance, J.M.

2004 Republic of Texas. The Handbook of Texas Online. http://www.tsha.utexas.edu/handbook/online/articles/viewRR/ mzr2.html. Accessed January 27, 2009.

Nickels, D.L. and R.P. Mauldin

2001 The Project Environment. In An Archaeological Survey of Twin Buttes Reservoir, Tom Green County, Texas, edited by R. Mauldin and D.L. Nickels, pp25-38. Archaeological Survey Report, No. 300, Center for Archaeological Research, The University of Texas at San Antonio.

Pérez et al. vs. Paschal et al.

1847 Bexar County Court House, District Court Records, District Clerks Office, B304-352. Originals on file in Bexar County Courthouse, San Antonio.

Perttula, T.K., M.R. Miller, R.A. Ricklis, D.J. Prikryl, and C. Lintz

1995 Prehistoric and Historic Aboriginal Ceramics in Texas. Bulletin of the Texas Archeological Society 66:175-235. 
Ricklis, R.A.

1992 The Spread of the Late Prehistoric Bison Hunting Complex: Evidence from the South-Central Coastal Prairie of Texas. Plains Anthropologist 37(140):261-273.

Sierra Club

2005 Alternative Water Management Strategies for the 2006 South Central Texas Regional Water Plan. Sierra Club, Lone Star Chapter, Austin.

Slattery, R.N. and L.D. Miller

2004 A Water Budget Analysis of Medina and Diversion Lakes and the Medina/Diversion Lake System, with Estimated Recharge to Edwards Aquifer, San Antonio Area, Texas. U.S. Department of Interior.

Story, D.A.

1985 Adaptive Strategies of Archaic Cultures of the West Gulf Coastal Plain. In Prehistoric Food Production in North America, edited by R.I. Ford, pp. 19-56. Anthropological Papers No. 75. Museum of Anthropology, University of Michigan, Ann Arbor.

Taylor, F.B., R.B. Hailey, and D.L. Richmond

1991 Soil Survey of Bexar County, Texas. United States Department of Agriculture, Soil Conservation Service. Washington, D.C.

Texas Historical Commission (THC)

2008aTexas Archaeological Sites Atlas. http://www.nueces.thc.state.tx.us. Accessed May 12, 2008.

Texas Historical Commission (THC)

2008b Texas Historic Sites Atlas, Enoch Jones Farmstead. http://atlas.thc.state.tx.us/common/viewform.as?atlas num=5029011746\&site. Accessed December 4, 2008.

Turner, S.E., and T.R. Hester

1993 Stone Artifacts of Texas Indians. Second Edition. Texas Monthly and Gulf Publishing Company, Houston.

Ulrich, K.M, J.J. Dowling, B.K. Moses, K. Hindes, J. Thompson, L.K. Wack, B.A. Meissner

2009 Testing and Mitigation at the Pérez Ranch (41BX274), San Antonio, Bexar County, Texas. Archaeological Report Draft. Center for Archaeological Research, The University of Texas at San Antonio.

Von Ormy Historical Society (VOHS)

2008 Palo Alto College History Project. http://www.vonormytexas.com/vohs/paloaltocollege.shtml. Accessed December 4, 2008.

Wade, $\mathrm{M}$.

2003 The Native Americans of the Texas Edwards Plateau, 1582-1799. The University of Texas Press, Austin.

Wallace, E.

1965 Texas in Turmoil: The Saga of Texas, 1849-1875. Steck-Vaughn, Austin

Weddle, R.S.

1968 San Juan Bautista: Gateway to Spanish Texas. The University of Texas Press, Austin. 
Weston, J.D.

2004 The Pérez Ranch Project: Reassessment of Four Archaeological Sites in South-central Bexar County, Texas. Archaeological Survey Report, No. 346. The Center for Archaeological Research, The University of Texas at San Antonio. 
